\title{
Storage amidst early agriculture along the Nile: Perspectives from Sai Island, Sudan
}

\author{
Elisabeth Anne Hildebrand ${ }^{1 *}$, Timothy M Schilling ${ }^{2}$ \\ *corresponding author \\ ${ }^{1}$ Anthropology Department, Stony Brook University \\ Stony Brook, NY 11794-4364 \\ elisabeth.hildebrand@stonybrook.edu \\ ${ }^{2}$ Midwest Archeological Center, National Park Service \\ Lincoln, NE 68502 \\ tim_schilling@nps.gov
}

\begin{abstract}
The transition to an agricultural economy hinges on both the presence of domestic plants, and the reorganization of labor and storage practices so that crops play ever-larger roles in human subsistence. Examining agricultural origins through the lens of changing storage practices offers novel insights about possible motives for early farming, and a clearer focus on how some of the "consequences" of agriculture - e.g. sedentarization, intensification of resource use, occupational specialization, and social differentiation - unfolded in specific times and places depending on management of physical storage facilities. In the Sahara and Nile, people prioritized different kinds of storage (social, physical, and environmental) in response to the changing opportunities and constraints they faced during early and middle Holocene times. Environmental storage (herding) held sway across much of northeast Africa until environmental deterioration pushed human populations into a small area near the Nile, where they developed physical storage facilities in the Fayum and Nile from the Delta south to Kerma. Discovery of wheat/barley in Sudan cemeteries predating these storage facilities suggests that herders were aware of southwest Asian crops for centuries before large-scale physical storage and regular farming took hold. Analysis of site 8-B-52A on Sai Island shows the gradual development of a major storage facility that was used for centuries by local people who produced and processed southwest Asian crops, and undertook construction and maintenance without external input or control by a centralized authority. Sai's record contrasts with other areas along the Nile, where large-scale facilities quickly triggered profound social changes. Although food security needs motivated northeast Africans to undertake farming of southwest Asian crops and invest in physical storage facilities, people managed storage in locally distinctive ways. Only in a few places did they rapidly translate the practice of storage into new social and economic spheres that fostered social differentiation, long-distance trade and, ultimately, the centralized polities of Ancient Egypt and Kerma.
\end{abstract}

\section{KEYWORDS}

Northeast Africa; Sai; Sahara; Nile; Holocene; storage; pits; food production 


\section{INTRODUCTION}

How and why humans store food has captured the attention of archaeologists for decades. The nature of, and motivations for storage practices have varied across space and time, both among hunter-gatherers (Binford 1980; Cunningham 2011; Testart 1982; Wiessner 1982) and food producers (Bogaard et al. 2010; DeBoer 1988; Wesson 1999). Storage is an important buffering mechanism that humans use to mitigate fluctuations in resource abundance (Halstead \& O'Shea 1989:3-4; Minc \& Smith 1989:10; Rowley-Conwy \& Zvelebil 1989). In many parts of the world, as prehistoric hunting and gathering populations reduced their mobility or began farming, people developed increasingly sophisticated, larger-scale technological mechanisms for 'physical storage' of food (e.g. Akazawa 1986; Minc \& Smith 1989; Pearson 2006; Sakaguchi 2009; Zvelebil \& Rowley-Conwy 1986). These innovations in storage are thought to have been linked to the advent of farming and settled village society, and the sequestering of resources for specialists or emerging elites (reviewed by Testart 1982:524). In diverse economic contexts in prehistory, transformations in storage practices allowed the creation of surpluses that initially countered risk or seasonal scarcity, but eventually fostered intra-community social differentiation and 'accumulation ideology' (reviewed by Zvelebil 1986; see also Barrier 2010:216; Coupland 1988; Flannery 1972; Halstead 1989:79-80; O'Shea 1981; Rowley-Conwy \& Zvelebil 1989; Sassaman 2004:240; Soffer 1989:722; Winters 1974; Wesson 1999).

As northeast African fishing/hunting/gathering economies incorporated livestock management and subsequently reoriented to farming of southwest Asian crops near the Nile (reviewed by Marshall \& Hildebrand 2002), people experimented with different kinds of storage. Large-scale storage facilities along the Nile are linked to the adoption of southwest Asian crops and the subsequent emergence of regular long-distance trade. Arguably, physical storage fostered changes in social organization that spawned the Egyptian civilization and the Kerma state (Allen 1997; Hassan 1988; Honegger 2004a). Local variations in the nature of these changes may have contributed to the ultimate configuration of polities along the Nile into recent times.

New data from Sai Island, northern Sudan offer a window onto the reasons for these local variations, and how they fit into more long-term shifts in storage practices. Sai was used by fisher-hunter-gatherers during early Holocene times, by herders ca. $5000 \mathrm{bp}^{1}$, and by people engaged in plant food production from ca. $4200 \mathrm{bp}$ on (Garcea \& Hildebrand 2009). The PreKerma (ca. 4700-4100 bp) site of 8B52A has some of the earliest evidence for farming along the Sudanese Nile and a storage facility with at least 134 pits. Documenting their size and configuration can help us evaluate possible relations between the development of physical storage facilities and the advent of farming of southwest Asian crops.

In this article, we address three key questions about socioeconomic organization and the transition to farming in this region. First, what motivated people on Sai Island to begin farming, and to construct the storage pit facility at 8B52A? Second, was the pit facility a local or a nonlocal undertaking? Third, to what extent did the development of physical storage on Sai Island echo or diverge from trajectories of socio-economic change elsewhere along the Nile?

\subsection{Storage, economy, and society}

Humans have deployed a tremendous variety of storage strategies from Pleistocene times to the present (Binford 1980; Cunningham 2011; Ingold 1983; Minc \& Smith 1989; Rowley-Conwy \&

\footnotetext{
${ }^{1}$ All dates are uncalibrated ${ }^{14} \mathrm{C}$ bp unless otherwise indicated.
} 
Zvelebil 1989; Testart 1982; Wiessner 1982). Scholars distinguish between four kinds of storage: Biological (formation of fat within the human body), social (networks of sharing, gift-giving and reciprocity that temporarily mitigate scarcity) (O'Shea 1981; Wiessner 1982), environmental (raising livestock to store food and other resources “on the hoof") (Brenton 1988), and physical (placing food in receptacles such as pots, granaries, or pits for later use) (O'Shea 1981; Halsted \& O'Shea 1989:4). ${ }^{2}$ In the northeast African context, we will examine the shift from mainly environmental storage (herding) to large-scale physical storage of southwest Asian crops.

The utility of each type of storage depends on the predictability and duration of lean periods, resource perishability and distribution on the landscape, and the settlement patterns and social ethos of particular societies (Testart 1982:524). Storage types also vary in compatibility with other forms of risk reduction, such as mobility, diversification, and exchange. Often, mobility and physical storage are seen as mutually incompatible, yet research demonstrates that mobile groups did practice subterranean physical storage (Rowley-Conwy \& Zvelebil 1989:47; DeBoer 1988).

Storage practices carry social consequences. On the one hand, social storage may impede the development of inequality by mitigating variations in resource access. On the other hand, environmental storage can foster inequities via disparities in livestock holdings; however, droughts and disease can quickly wipe out advantages, and the mobility inherent in herding impedes accumulation of goods that might perpetuate or amplify disparities. In contrast to the other two storage types, physical storage may promote more permanent forms of socio-economic inequality - especially large-scale facilities that may come under the control of a few individuals, or small-scale, family-controlled facilities that preserve and amplify intra-community disparities in production (Hitchcock 1982:250; Testart 1982; Wesson 1999). Alternatively, hidden physical storage facilities may help people conceal food stores from hostile outsiders, elites seeking tribute, or indolent members of their own group (DeBoer 1988). These global perspectives are an important framework for considering transformations in storage practices in the Sahara and Nile: they suggest that the shift from environmental to physical storage may have triggered major social changes, but the exact nature of these changes hinged on specific contextual factors.

\subsection{Evidence for storage in the Sahara/Nile, and interpretive dilemmas}

Between the onset of the hyperarid conditions of the Last Glacial Maximum and the advent of settled farming communities, people employed many approaches to storage - as basic as drying food to provide for lean seasons at Wadi Kubbaniya, and as sophisticated as the specialized pastoral systems that developed around Khartoum $5500 \mathrm{bp}$. These innovations are striking for their diversity, and the distinct environmental, economic, and social contexts in which they arose (Table 1).

\section{***TABLE 1 and FIGURE 1 would be placed around here****}

African fisher-hunter-gatherers practiced small scale-physical storage during Pleistocene and Early Holocene times. More substantial physical storage facilities accompany the onset of farming of southwest Asian crops in many parts of northeast Africa. Interpreting the economic and/or social motives for initial large-scale storage facilities is challenging, however. Was their

\footnotetext{
${ }^{2}$ Terminology pertaining to different storage types and scales varies from author to author (see Brenton 1988; Ingold 1983:556-561; O’Shea 1981; Cunningham 2011:138).
} 
use temporary, seasonal, or long-term? Were they managed by households, networks of extended kin, entire communities, or aspiring or established elites? Were they securing food resources, or other goods? Interpretive dilemmas are especially keen when physical storage facilities and farming emerge in tandem, because many economic practices and social roles must have been under negotiation.

In some cases, physical storage may serve to minimize risk, or convert a seasonal abundance gained from new crops into something the society can rely upon during periods with scant wild resources. Alternatively, social models of food production (Hayden 1990, 2009) raise the possibility that aspiring leaders may instigate both the adoption of crops and the construction of storage facilities to advance their aims. A third possibility is that people may build and use subterranean storage facilities to conceal surpluses from elites.

One cannot assume that any one of these motives held sway. Indeed, different motives may have compelled construction of different storage facilities in different places, and prior economic conditions and experiments in various modes of storage may have shaped motives. Each of these possibilities carries a set of expectations (unfortunately not always mutually exclusive) regarding the size, location, and configuration of the storage facility (Table 2).

\section{***TABLE 2 would be placed around here ***}

\section{DID SOUTHWEST ASIAN CROPS TRIGGER CHANGES IN STORAGE IN NORTHEAST AFRICA?}

In Egypt, large-scale built storage seems linked to certain environmental and economic events. Environmentally, it coincides with the major desiccation that returned the Sahara to desert conditions, forcing humans to converge on the Nile, Fayum, and oases as linear or point refugia. Economically, it appears to correlate with the spread of southwest Asian crops into the Fayum, Nile Delta, and south to Upper Egypt (Table 3, Fig. 1). Changes farther south among the AGroup, northern Sudanese Neolithic and Pre-Kerma cultures have seen less attention, but suggest complicated relations between environmental change, access to southwest Asian crops, and physical storage.

\section{***TABLE 3 would be placed around here ***}

\subsection{Lower Nubia: A-Group}

Between the $1^{\text {st }}$ and $2^{\text {nd }}$ Cataracts, A-Group sites (4700-3900 bp) have fine, thin, burnished ceramics, stone bowls, and glossy blades (Gatto 2006; Lal 1967; Nordström 1972). Most lie near floodplains (Nordström 1972:22), but some occur up to $300 \mathrm{~km}$ west of the Nile (Lange 2006, 2007). A diverse economic regimen included hunting and fishing; farming domestic wheat, barley, and legumes; and herding cattle, sheep, and goats. Economic foci may have shifted from more inland herding during earlier, wetter phases, to more farming near the Nile during later, drier phases (Gatto 2006; Lange 2007).

A-Group sites often consist of temporary camps, but Afiyah has storage pits amidst permanent houses with stone foundations (Gatto 2006; Lal 1967; Nordström 1972:20-21). Early A-Group cemeteries (e.g. Khor Bahan) have little indication of social differentiation (Gatto 2000), but late phases of A-Group show social differentiation suggestive of a "proto-state" engaged in trade with Egypt (Gatto 2006). Wide networks of exchange and inter-cultural 
interaction are evident via A-Group pottery at Nagada sites farther north and Pre-Kerma sites farther south (Garcea \& Hildebrand 2009; Gatto 2006).

The site of Khor Daoud has evidence for large-scale storage (578 pits) (Nordström 1972:26). It has little evidence for habitation, but lies near several A-Group sites. No absolute dates exist for the site, but abundant Predynastic pottery attests to a long period of use from the middle to terminal Predynastic times, and intensive use during Gerzean times 3700-3300 BCE ( 4700 bp). Khor Daoud may be interpreted as a setting for periodic exchange between mobile herders, people living near the Nile, and/or representatives of Predynastic populations (Nordström 1972:26).

Together A-Group data suggest small-scale storage occurs with the earliest evidence for farming in Lower Nubia; however large-scale storage appears at a trading entrepot that did not sustain permanent habitation by A-Group people, suggesting that agricultural surplus was used for exchange between people of different cultural groups. Because Khor Daoud was used over the entire chronological range of A-Group material culture, we see no sign of a gradual "ramping up" of facilities from storage of seasonal foodstuffs to commodities. Rather, food production, both small- and large-scale storage, and long-distance exchange all take hold together, and social differentiation within the A-Group culture follows.

\subsection{Upper Nubia \& Central Sudan: Neolithic}

Finds from recent excavations in Upper Nubia and central Sudan challenge prior views that the Neolithic of northern Sudan focused on animal husbandry and lacked domestic plants. Three cemetery sites - KDK-1 (Reinold 2000, 2001, 2006), and R12 and el-Ghaba (Madella et al. 2014) - have shown southwest Asian crops by $6240 \pm 40$ bp, predating currently known finds in Egypt.

KDK-1 is one of several cemeteries excavated in the Kadruka plain. Its homogeneous material culture indicates a short use period ( 100 years) (Reinold 2001). Dates of 5290 $\pm 60 \mathrm{BP}$ (3340 BCE) and 5360 \pm 70 BP (3410 BCE) make it one of the latest Neolithic cemeteries in Sudan (Reinold 2006). Ninety-six Neolithic burials lie in separate areas for males and females. Burial KDK-1-131 is spectacular, with yellow-tinted bovid skin, ivory bangles, agate beads, an anthropoid figurine, miniature axes in stone and ivory, two groups of mace-heads, two bucrania, two combs, two goblets, and a large jar (Reinold 2001, 2006). Burials in concentric circles around KDK-1-131 also have offerings, with density diminishing away from the center. Mace heads, goblets, palettes, anthropomorphic figurines, and seashells appear only in upper parts of the cemetery with male burials. Other offerings (bucrania, axes, pigment cases, painted vases) occur throughout KDK-1 (Reinold 2006). Some burials are placed on leather cushions filled with barley (Reinold 2001).

Reinold (2001) interprets Neolithic cemeteries in the Kadruka area as serving dense populations of people who farmed domestic crops on the fertile alluvial plain east of the Nile. However, barley is only found at KDK-1, one of the latest cemeteries, and it is the only domestic plant recovered - indigenous cereals are wild. Although people had livestock throughout the Sudanese Neolithic, there is no evidence for settled village agriculture. The remarkable funerary context of KDK-1 suggests that the barley might have been included as an exotic trade item that held special value or symbolism, rather than as an indicator of quotidian habits.

Unfortunately, severe deflation has compromised the contextual integrity of settlement sites on the Kadruka plain (Reinold 2006:1), making it difficult to evaluate the nature and extent of barley use, or the relative importance of herding vs. aquatic pursuits vs. the farming suggested 
by Reinold (2001). Research at Kadruka has privileged cemeteries over settlements, but it is interesting that no remains of mud-brick architecture, pits or other indications of long-term settlement or storage facilities have been described.

More evidence for use of wheat and/or barley comes from R12 near the $3^{\text {rd }}$ Cataract and El Ghaba in central Sudan, where lenses of silica-rich material beneath human remains were sampled for phytoliths (Madella et al. 2014; Salvatori \& Usai 2008). At R12 contexts dated to $6240 \pm 40 \mathrm{bp}$ (5311-5066 cal BCE) yielded Triticeae phytoliths that must be ascribed to wheat and/or barley because no wild Triticeae taxa are known in northern Sudan. At El-Ghaba contexts dated to $6620 \pm 40 \mathrm{bp}(5620-5480 \mathrm{cal}$ BCE) and 5800 $\pm 40 \mathrm{bp},(4730-4540 \mathrm{cal}$ BCE) phytoliths from similar contexts include some Triticeae, but also indigenous (likely wild) taxa such as Echinochloa, Brachiaria, other Paniceae, and Sorghum. Starch grains from dental calculus yielded identifications of Faboideae at R12, and Faboideae, Panicoideae, and Triticeae at ElGhaba.

Like KDK-1, the cemeteries at R12 and El Ghaba prove early access to southwest Asian crops: R12 finds predate the earliest Egyptian finds. Triticeae starch in dental calculus shows ElGhaba people ate wheat and/or barley. Still, without settlement archaeology in these areas, one cannot determine whether these exotic crops were grown locally or imported, or whether and how local or exotic cereals were stored.

\subsection{Upper Nubia: Pre-Kerma}

The Pre-Kerma archaeological culture was first defined by Bonnet (1992), based on extensive remains of settlement and architecture (pits and alignments of post holes) underlying/predating cemeteries at the Kerma site. Pre-Kerma pottery has some affinities to A-Group pottery farther north, and to later ceramic traditions of the Kerma culture, but is distinctive in having dung temper. Today, Pre-Kerma sites are known between the $2^{\text {nd }}$ Cataract and the Dongola Reach.

On Sai Island, Pre-Kerma site 8-B-52A has clear evidence for physical storage: at least 134 pits far from the Nile shore. Pottery is dominated by the Pre-Kerma tradition, with a small proportion of A-Group ceramics and one Egyptian vessel (Garcea \& Hildebrand 2009; Geus 2000:127). Emmer wheat and barley are present within the pits, the latter directly dated to ca. 4150 bp (Geus 1998-2002:67). Cucurbitaceae, Ziziphus, and Acacia seeds are also found.

8-B-52A has no evidence of habitation. Across the wadi, 8-B-53 was initially regarded as a possible contemporaneous habitation, but décapage and excavation yielded scant evidence for human use. Sai Island's gently sloping southeast floodplain would have furnished abundant wild resources and fertile grounds for cultivation across an large area, extending from previously described Khartoum Variant site 8-B-10C southwest through 8-B-10A, which has surfaces rich in pottery from Pre-Kerma to Classic Kerma times. Initial soundings at 8-B-10A have not yet found occupation layers contemporaneous to 8-B-52A, but it is possible that the people who built 8-B-52A inhabited some part of Sai's southeastern shore some $3 \mathrm{~km}$ from the storage facility.

South of the $3^{\text {rd }}$ Cataract, basal layers at Kerma contain a Pre-Kerma horizon with $>280$ pits (Bonnet 1992; Honegger 2003, 2004a,b). Although the pits likely stored foodstuffs, no domestic or wild plants have been identified. Interspersed with the pits, postholes demarcate aboveground structures. Most are round huts c. $4.2 \mathrm{~m}$ in diameter. A few round structures $>7 \mathrm{~m}$ in diameter, and two rectilinear structures, may have served special functions. Fences or walls and earthen mounds lie outside of these structures (Honegger 2004a).

Dating its occupation to 4400 bp/3000 BCE, or 'Middle Pre-Kerma' times, Honegger postulated the existence of an earlier, as yet undiscovered 'Early Pre-Kerma' phase postdating 
the latest 'Neolithic' sites c. 5500 bp; Other Pre-Kerma sites in the vicinity dating to 4300-4100 bp are 'Late Pre-Kerma' (Honegger 2004b:39,45). Soon thereafter (c. 3900-3300 bp), the site of Kerma developed into a large town with distinct subareas including a religious quarter. Monumental architecture took the form of an exceptionally large (10 m high) "hut" structure with mixed construction elements (wood, mud-brick, and fired brick), extended ditch fortifications, and the enormous deffufa monument in the center of town. These developments, along with increasingly ostentatious mortuary arrangements, herald the start of a state centered at Kerma, whose sphere extended downstream to Sai and upstream to the $4^{\text {th }}$ Cataract (Bonnet 1992, 2006). The Kerma kingdom is assumed to have had an agricultural subsistence base, but the crops grown, and the manner in which they were farmed, is not known.

\subsection{Rethinking the impact of SW Asian crops}

Evidence from these three distinct archaeological cultures - A-Group, northern Sudanese Neolithic, and Pre-Kerma - challenge notions of southwest Asian crops spreading steadily up the Nile into pastoral areas and being embraced as soon as they became available. The finds of Triticeae at R12 and El-Ghaba are remarkable in predating evidence of farming in Egypt. While earlier farming sites on the Egyptian Nile may be unfound because they are covered over by fluvial silt deposits, such recovery bias should not have affected the thoroughly-researched record from the Fayum; one is forced to conclude that adoption of farming was not universally immediate. Along Sudanese stretches of the Nile upstream to the $6^{\text {th }}$ Cataract, it is clear that people must have been aware of wheat and barley for centuries, even millennia before they focused on farming or undertook to build the large-scale storage facilities evident in A-Group and Pre-Kerma sites. Knowing that opportunity was ever-present, we must reconsider motives: What factors initially delayed the decision to take up farming? How did these factors eventually shift in favor of agriculture? We probe the second question by examining evidence from Sai Island, where 8-B-52A's architectural features lend important contextual perspectives on role storage played in the formation of a farming economy.

\section{STORAGE ON SAI ISLAND}

\subsection{Geological and environmental context}

The development of physical storage at Sai relates to its topography and geology (Figure 2). Mudstone from the Nubian Sandstone Formation crops out or can be found at shallow depth in several places on Sai Island. The mudstone stratum is several meters thick, and unconformably capped by Pleistocene pediment. At 8 -B-52A, Pleistocene deposits thin to reveal about $1 / 4$ hectare of soft pale mudstone bedrock.

\section{***FIGURE 2 would be placed around here***}

The elevation, composition, and hardness of the mudstone varies across the island. In some locations the mudstone is so hard it is unworkable, whereas in others it readily fragments when touched. 8-B-52A is one of the few places on Sai where this mudstone is both visible between discontinuous overlying layers of Pleistocene gravels and occasional deposits of Holocene silts - and has intermediate friability ideal for construction: Prehistoric people were able to scraped and dig the mudstone with effort, but it does not collapse under moderate pressure. 
During the early Holocene, annual rainfall of $300-450 \mathrm{~mm}$ would have supported moderate vegetative cover at Sai (Wickens 1982). High Nile flow would have confined the island to a 9 × $3 \mathrm{~km}$ area corresponding to the Pleistocene pediment (Figure 2). Gradual decreases in precipitation across the eastern Sahara reduced vegetative cover in non-inundated areas such as Sai's Pleistocene pediment and mainland areas away from the Nile. By 6300-4700 bp, areas around Sai would have received just 150-300 mm annual rainfall (Kuper \& Kröpelin 2006). Nile flow decreased and became unpredictable; river levels fluctuated (Nicoll 2004). Some floodplains may have narrowed, but those on Sai's eastern edge may have enlarged as the channel shifted east (Geus pers. comm. 2004). By 4500 bp, vegetation away from the Nile was minimal in northern Sudan (Nicoll 2004).

Today, Sai Island is $12 \times 5.5 \mathrm{~km}$ between the main (east) and minor (west) channel; plant and animal life is confined to the Nile, its floodplains, and irrigated areas. $8-\mathrm{B}-52 \mathrm{~A}$ is $>1 \mathrm{~km}$ from either channel of the Nile. A paleochannel may still have flowed closer to the site during middle Holocene times. But aside from Jebel Adou, 8-B-52A is at one of the highest points on Sai Island, and would have been safe from inundation.

A shallow wadi running through exposed mudstone defines the southern and western limits of the site. Pits appear to extend $\sim 20 \mathrm{~m}$ to the east of the main excavation area, and $\sim 20 \mathrm{~m}$ to the north (Figure 3). The site's northeastern boundary may result from the plunging surface of mudstone: $10 \mathrm{~m}$ farther northeast, the profiles of excavated Meroitic tombs show the mudstone in that area eroded substantially before deposition of the Pleistocene gravel bar $>1 \mathrm{~m}$ thick. Thus 8-B-52A used nearly all of the available area where semi-friable mudstone bedrock was conveniently accessible at or near the surface.

\section{***FIGURE 3 would be placed around here***}

\subsection{Methods}

Francis Geus (1998, 1998-2002, 2000, 2004) initiated research at 8-B-52A. In 1996-7, Geus' team first exposed and excavated $10 \times 10 \mathrm{~m}$ area on the eastern side of 8-B-52A (Meurillon 1997). In 2002-3, Geus' team extended the excavation area westward and began profiling pits. Surface cleaning extended north and south of this western area (Fig. 3). Four additional 5 x $5 \mathrm{~m}$ areas farther north were also cleaned to determine the extent of the site, and some pits discovered during this process were also excavated (Geus archive notes, n.d.). Excavation and surface cleaning revealed that pits were sealed using sunbaked daub material with a mudbrick-like consistency. Geus' team removed daub chunks $(\sim 10 \times 10 \times 3 \mathrm{~cm})$ from the upper pit margins, and stored them in 50-kg sacks made of plastic mesh. Sieved sediments from inside the pits yielded plant materials, pottery, and other finds.

In 2004, EH joined Geus' team as archaeobotanical specialist. Following Geus' unfortunate death in 2005, EH and TS continued research at 8-B-52A (Hildebrand 2006-2007). Because two Geus campaigns had employed slightly different spatial documentation methods, our 2005-2008 fieldwork focused on achieving a single, comprehensive spatial data set across the site. This entailed some re-excavation to record pit profiles in the Geus' 1996-7 area, and high-resolution surface mapping of the 2002-3 excavation area. Seeking a contemporaneous habitation site on Sai's southeastern floodplain, we also surveyed 8-B-10A, excavated two 1 x 2 units to sterile substrate and bedrock, and obtained three dates from the test unit with higher artifact densities. 
Flotation of plant remains from daub and other contexts was done at Sai across several field seasons from 2004 to 2009. Before disaggregating the remains for flotation, surface contaminants were removed by dry brushing. We did not identify any obvious signs of turbation or post-depositional disturbance that would have introduced non-archaeological materials into the daub. We used clean well water for flotation and it was done indoors, away from strong winds and other potential sources of contamination. Float sample volumes varied depending on the quantity of daub recovered from each silo. Light fractions were sieved using $0.5 \mathrm{~mm}$ mesh and heavy fractions used $1.0 \mathrm{~mm}$ mesh. Preliminary results show that chaff is a primary constituent of the daub. The chaff is typically fine plant material of variable composition, including fine charcoal vs. uncharred stem and leaf tissue vs. winnowing waste products. Wild plant remains found in the pits (Acacia, Zizyphus, Cucurbitaceae) are, for the most part, absent from the daub. While it is possible that animal dung formed a substantial portion of the daub, the presence of charcoal, rock granules, and pebbles indicate other elements were deliberately added. Pit-to-pit variation in these elements and their ratios suggests little in the way of standardization. It is probable that each daub seal was created and applied independently over time.

Currently 8-B-52A has seven radiocarbon age determinations from a variety of contexts. Geus (1998) obtained from two grains of barley recovered from Silo 1 and Silo 11. Following flotation of daub to amplify recovery of macrobotanical remains (Hildebrand 2006-2007), we selected dating samples from five pits representing different parts of the excavated portion of 8B-52A. Because the antiquity of barley at 8-B-52A was already confirmed, we purposely selected unidentifiable plant remains for dating from the light fraction of floated daub, rather than sacrificing identifiable material for destructive analysis. Charcoal pieces were available in daub from Silos 70, 26, and 10, whereas light chaff material was available in daub from Silos 11 and 39; together, these samples generated five more dates for 8-B-52A.

\section{RESULTS}

Building on earlier attributions of 8-B-52A to Pre-Kerma times based on its ceramic assemblage and two radiocarbon measurements on pit contents (Geus 1998, 1998-2002, 2000; Garcea \& Hildebrand 2009), new AMS dates on chaff from daub pit seals extend the documented chronology for Pre-Kerma back by 400 years to $4800{ }^{14} \mathrm{C}$ bp. These dates, coupled with spatial data on the form and layout of the pits, help show the organization of activities at 8-B-52A over time.

\subsection{Chronology of construction and use of 8-B-52A}

Radiocarbon dates obtained from pit contents ( 2 dates) and daub seals ( 5 dates) demonstrate that construction and use of 8-B-52A likely spanned $>800$ years, from c. 3600 to $2600 \mathrm{cal}$ BCE (Table 4).

\section{***TABLE 4 and FIGURE 4 would be placed around here ***}

Dates on chaff derived directly from massive daub caps integral to pit construction shed light on the degree of contemporaneity in these activities across the site. ISGS dates A1741, A1764, A1742, and A1763 all have calibrated ranges that exhibit no overlap whatsoever (Table 4, Figure 4). Together they suggest that pit construction and use, whether continuous or sporadic, 
occurred over a very long time. The site was not built in a single organized event, nor was it originally conceived of as a large-scale facility.

These new dates bear on regional chronology of the Pre-Kerma period. Dates A1741 (4865 $\pm 20 \mathrm{bp}$ ) and A1764 (4730 \pm 20 bp) demonstrate that the site was used during the 'Early PreKerma' period postulated by Honegger (2004b:45). The others, collectively spanning 4300-4070 ${ }^{14} \mathrm{C}$ bp, tally with Middle and Late Pre-Kerma dates obtained by Honegger around Kerma. Honegger (2004b) has noted the absence of evidence for 'Early Pre-Kerma' sites or contexts farther south near Kerma. Perhaps the Pre-Kerma cultural entity initiated near Sai and elaborated at Kerma, where an extended plain allowed farming on a larger scale. Alternatively, Early PreKerma contexts may await discovery in the Kerma area. Further research is needed near Kerma to clarify this point.

Our soundings at 8-B-10A on Sai's southeastern floodplain yielded three dates with overlapping ranges $\sim 3500-3400 \mathrm{bp} / \sim 1900-1650$ BCE. These correspond to Middle Kerma and earliest Classic Kerma periods defined at Kerma itself (Bonnet 1992). Because these clearly postdate use of 8-B-52A, and represent a small sounding across a vast archaeological landscape, efforts to find habitation remains dating to Early and Middle Pre-Kerma times must continue at Sai.

The new dates from daub seals alter the chronological position of 8-B-52A versus developments in Egypt. Geus' initial dates of $\sim 4150$ bp (2880-2581 BCE) had a calibrated range overlapping with the $2^{\text {nd }}-4^{\text {th }}$ Dynasties, raising the possibility that 8 -B-52A construction was stimulated by contact with the Egyptian state. However, new dates from Silo 70 ( 4865 bp, 3696-3637 BCE) and Silo 26 ( 4730 bp, 3632-3380 BCE) put initial construction in Predynastic times, centuries before Egypt had a centralized polity.

Geus' (1998) dates for early barley still stand as Sai's earliest evidence for farming. Their larger calibrated ranges reflect their larger lab errors and fluctuations in atmospheric radiocarbon (Figure 4). Barley dates overlap heavily with the age range for construction of Silo 39, and partially with that for Silo 11. At least by Middle Pre-Kerma times, the people using 8-B-52A stored southwest Asian crops, and probably produced them locally. Future dating of domestic plant remains in daub may reveal earlier evidence for farming.

\subsection{Spatial organization of 8-B-52A}

Pre-Kerma people positioned their storage facility where they could reach the strong yet workable mudstone bedrock easily, and create durable pits within this ideal medium.

\subsubsection{Pit morphology}

Out of 134 pits identified, 72 were excavated by Geus' team. Of these, 57 had distinct shapes that could be classified into one of three general categories. Most pits were either bell shaped, cylindrical, or basin shaped (Figure 5). A few had an hourglass shape, combining a large, upper basin-shaped chamber with a smaller lower chamber whose orifice was restricted. Nine were badly eroded or had ambiguous shapes. Although pits may have served multiple functions, some had schist slabs sealing the orifice and intact contents. In these instances, the pits were not lined or prepared beyond excavation but they appear to have been used to store grain. Some other pits contained pottery vessels (Geus 2000), which may have held different kinds of foods or other items. In one pit (Silo 23) remains of a pottery vessel broken in situ may indicate secondary containers were placed within pits. The contents of the vessel were not preserved. 


\section{***FIGURE 5 would be placed around here***}

Although we classified pits by shape, the function and meaning of morphological differences is uncertain. Pits with restricted orifices could store unsecured materials like threshed grain, which could be poured through a narrow aperture; pits with unrestricted orifices may have been better suited to storing goods placed in large containers such as pottery vessels and leather sacs. However, observed variation in pit morphologies should not be uncritically linked to possible functional purposes, because current shape may be an artifact of wear due to human use or taphonomic processes. Basin-shaped and cylindrical pits may have originally started as bellshaped and slowly became less constricted with use (DeBoer 1988). Hourglass-shaped pits may have been purposely designed to have upper and lower chambers, or the lower chamber may have been dug to replace a defunct, collapsed upper chamber (Figure 5). Daub repairs to upper parts of pits signal attempts to restore narrower orifices that would be easier to conceal and/or seal with a single stone slab.

\subsubsection{Size, storage capacity, and organization of pits}

Pits had highly variable dimensions. Openings ranged from $0.15-1.5 \mathrm{~m}$ across; maximum diameters ranged from 0.25 to $>2 \mathrm{~m}$. Depths ranged from ca. $0.1 \mathrm{~m}$ for the shallowest basins to $>1.0 \mathrm{~m}$ for the largest cylindrical and bell-shaped pits (Figure 6), and double-chambered pits. Estimates of the total storage capacity for 8-B-52A, based on volumes of excavated pits and surface assessments of unexcavated portions of the site, are $40-92 \mathrm{~m}^{3}$.

\section{***FIGURE 6 would be placed around here***}

If one assumes that all pits were used concurrently, had prehistoric shapes akin to those observed today, and were fully loaded with grain, one might conclude that 8-B-52A could have supported a population of 100 to 235 people (after Hassan 1988:148-149). However, in light of the long chronology proposed here the local population supported by the pits was probably much smaller. The long span of radiocarbon dates suggests an extended period of construction, use, and eventual collapse of pits, such that only a minor portion of the set visible today were in use at any point. Some of the pits (particularly large basin-shaped ones) are likely to have had different original shapes and expanded and/or collapsed due to use or taphonomic processes. Even if the broader basin-shaped pits retain their original shapes, they would not have been secure places to store grain unless it was placed in secondary ceramic vessels whose combined volumes would have been far less than that of the pit; alternatively, wide basin-shaped pits may have served other purposes. Thus, it seems probable that 8-B-52A saw use by a smaller number of people - perhaps only a few families - over an extended period.

At least four groups of pits can be discerned among those excavated (Figure 3). These groups can be interpreted in multiple ways. On the one hand, households or kin groups may have claimed specific areas of the site and constructed multiple pits with complementary purposes in their area at one time. On the other hand, households or kin groups may have used only a single pit at any one time. If that pit collapsed or became unusable, they repaired it or dug a new one adjacent. Yet again, different groups of pits may represent successive efforts over time, made and used communally by a larger community comprised of several households or kin groups. Because the pits are superimposed on one another, better chronological control is needed to evaluate these and other possible interpretations. 


\subsubsection{Contemporaneous habitation and settlement patterns}

No contemporaneous domestic occupations have been identified at 8-B-52A. The pit features are close together and no traces of post holes are evident on the surface. Careful décapage of surface areas, and the excellent preservation of small pit features, together suggest that postholes would be visible if present. The neighboring site 8-B-53 had Pre-Kerma pottery on the surface and was initially thought to be a related habitation area. However, décapage and excavation of its Holocene sediments across a $4 \times 4 \mathrm{~m}$ area yielded only low densities of artifacts, and revealed no traces of occupational structures (Hildebrand 2006-2007). No other Pre-Kerma sites are known near 8-B-52A; the only other Pre-Kerma pottery found on Sai comes from multi-component site 8-B-10A on the SE floodplain which so far has produced dates later than those from 8-B-52A.

With no evidence yet for regular nearby habitation contemporaneous with 8-B-52A use, at least two models of Early and Middle Pre-Kerma settlement and economy are possible. First, people may have been mobile, farming seasonally but moving regularly at other times of year to more widely distributed pasture and wild resources. Second, people may have had sedentary or near-sedentary occupation on the island at one or more sites as yet undetected (possibly on the southeast floodplain and now overlain by Kerma-age habitation remains), and emphasized farming and riparian hunting and gathering over other means of subsistence. Archaeological evidence from Sai is not yet sufficient to favor one model over the other. In either case people may have stored some of their harvest in structurally sound, visually unobtrusive subterranean cavities higher than any possible inundation. It is possible that each mobility/economic strategy was employed at different times, or that an initially mobile, mixed economy gave way to a more sedentary, agriculturally focused economy as desiccation reduced productive environments away from the Nile shoreline.

\section{DISCUSSION}

As the earliest concrete evidence for local farming and storage of southwest Asian crops, 8-B52A sheds light on the advent of farming and the development of physical storage in northern Sudan centuries after Neolithic herders had access to southwest Asian crops. Dates from Sai reinforce a general link between the arid shift that finally made herding impracticable in inland areas, and the beginning of local farming and permanent storage along the Nile. Spatial data from 8-B-52A clarify aspects of these first farming societies, and how they deviated from previous lifeways. In the following section, we evaluate local vs. external instigation of the pit facility, examine motivations for its construction and use, compare Sai's sequence of changing storage methods with those in other parts of northeast Africa, and consider the sometimes complementary, sometimes competing roles of physical vs. environmental storage in meeting social and economic challenges.

\subsection{Was construction of the pit facility locally or externally instigated?}

Construction at 8-B-52A began too early to have been catalyzed by trading or military expeditions sent forth from a unified Egyptian state. Pit construction also appears to have begun earlier at Sai than at Kerma. Thus, it would appear that local agency was paramount in the initial conception and construction of pits on Sai Island.

The ceramic assemblage from 8-B-52A reinforces this picture. Pre-Kerma pottery

constitutes $98 \%$ of the assemblage and is dominated by heavy storage vessels. Around $2 \%$ of the 
sherds resemble those of the A-Group tradition, and include bowls and serving vessels (Garcea \& Hildebrand 2009:317-318). In addition, Geus (1998:93) noted the presence of a few Dynastic sherds. One can conclude that people at Sai Island had cross-cultural contact or down-the-line exchange with A-Group and (less frequently) Early Dynastic people, but the pits at 8-B-52A remained under control of a local Pre-Kerma population.

6.2. What motivated people on Sai Island to begin farming and constructing storage pits? Storage pits at 8-B-52A were constructed and used across a period of at least 800 years. At any given time between 3600 and $2800 \mathrm{bp}$, the scale of storage at 8-B-52A was probably small or moderate - perhaps up to a few dozen cubic meters, but not approaching the full capacity of the site. Domestic plants are demonstrated by the Middle Pre-Kerma phase, but may have been present earlier. Under these circumstances, untangling the exact motives Sai people had for undertaking farming and storage is complicated for two reasons.

First, the precise chronological relations between the earliest farming and initial pit construction at 8-B-52A are not yet clear. Farming of southwest Asian crops could have created the initial surplus that then stimulated construction of the pit facility. Alternatively, pits could have first been dug to store a variety of wild plant resources needed as resource areas contracted to the Nile corridor, and the existence of 8-B-52A may have hastened the adoption of farming to produce additional storable resources. Finally, the two events may have been practically simultaneous. At this point, with robust spatial and chronological data for 8-B-52A, we would like to reflect on possible motives for creating and maintaining a storage facility. Later, when archaeobotanical analysis is complete, it will be possible to see the relative emphasis of wild vs. domestic taxa among plant materials stored, examine motivations for early farming, and compare them to the storage motives we explore here.

Second, local settlement patterns are not well defined. Pits may have been caches for seasonally produced harvests accessed by mobile groups who also fished and herded. Ethnographic records of the Nuer document seasonal movements between focused settlements near cultivation areas, and more dispersed encampments as groups scatter to fish and find pasture (Evans-Pritchard 1940). In such an economic regime, a storage facility might serve as a central place where harvested crops and/or wild plant foods were placed for dispersed groups to return and access as needed. Alternatively, 8-B-52A could have been built by people with a heavier focus on farming or collection of wild plants, with a more sedentary pattern of habitation (possibly living near agricultural fields southeast shoulder of the island much of the year, and shifting to higher ground during inundation season). Thus several different sequences of change in economic strategy and storage technology are possible, and any motives that might have arisen under any of these sequences merit consideration.

A surplus stored at 8-B-52A might have been deployed in several different ways: 1) mitigating regular seasonal shortages, 2) reducing risk of subsistence shortfalls during bad years, 3) reserving food for feasts, 4) setting aside food for exchange, and 5) concealing surpluses from outside powers, local elites, or indolent members of their own group.

The first two motives - previously invoked to explain the spread of farming up the Egyptian Nile (Wetterstrom 1993) - could equally apply to the advent of storage at Sai. Early construction at 8-B-52A coincides with a major desiccation event that must have impacted inland resources for hunting, gathering, and herding, prompting intensified use of the riverine corridor. As productive areas contracted toward the river and inland alternatives diminished, seasonal fluctuations and year-to-year vagaries in resource availability would have amplified. Under these 
circumstances, people may turned to physical storage as a hedge against scarcity. It is difficult to conclusively support or dismiss these motives without a full complement of evidence from contemporaneous habitation sites, but both are plausible.

The third motive, feasting, is difficult to evaluate with current evidence. Within the context of 8-B-52A, the small volume of storage in play at any given time argues against the idea of large-scale surplus mobilization. Outside of 8-B-52A, no contemporaneous habitation sites have yet been found that might bear evidence of the possible forms of plant contributions to feasts (e.g., beer, bread, porridge), the kinds of required processing (e.g., grinding, fermentation, cooking, and baking), and the likely archaeological manifestations of processing and consumption on a large scale (e.g., numerous grindstones, large fermentation jars, griddles or ovens, and a large number and/or wide variety of serving vessels). Unless Early Pre-Kerma sites with such evidence are found, feasting will not gain traction as a primary motivator for either the adoption of farming or the initial construction of storage facilities such as 8-B-52A.

The fourth motive, sequestering food for exchange, has only weak support. The only trade goods at 8-B-52A are a few Dynastic sherds, which must have entered the site long after it was established, and the A-Group sherds, which constitute $<2 \%$ of 8 -B-52A's pottery. 8-B-52A has less evidence for long-distance exchange than Khor Daoud, the specialized storage site with abundant Predynastic pottery situated within the A-Group culture area. One may conclude that although some storage facilities along the Nile were constructed in part to serve long-distance exchange networks (e.g. Khor Daoud), this orientation was not universal.

The fifth potential rationale for construction - concealing surpluses - has several possible submotives. In a scenario of powerful outsiders periodically sending emissaries to the area, 8-B$52 \mathrm{~A}$ is located away from the river in a location that could remain undetected by such a visiting party. Because neither the Egyptian or Kerma states had emerged by the time construction of 8B-52A began, we cannot consider this a likely motive for the facility's initial creation, but it might have figured in later phases of 8-B-52A's use during early Dynastic times. For scenarios of attempted surplus concealment from either local elites or indolent community members, 8-B52A's large size, elevated location, and permanence would almost guarantee detection. Traffic across the north end of the island is visible from most directions, even as far as the pediments above opposite shores of the Nile, and once the facility was created it must have been common knowledge of most local inhabitants. A better strategy for concealing surplus from an upstart leader or lazy neighbor would be to "hide it in plain sight" somewhere nearby where it could be easily and quickly moved and removed, not in a permanent facility situated on an elevated plain requiring an extended walk with a heavy load in full view of everyone for several kilometers.

\subsection{To what extent did the development of physical storage on Sai Island echo or diverge from trajectories of socio-economic change elsewhere along the Nile?}

Current evidence suggests concerns about seasonal or long-term fluctuations in resource ability spurred initial construction of storage pits on Sai Island. In a general way, this echoes findings from the earliest storage facilities in the Fayum, the Nile Delta, Upper Egypt, and Lower Nubia. But specific aspects of initial storage facilities, and ensuing economic and social changes, varied dramatically from area to area.

Initial storage facilities: mobility and organization

Initial storage facilities in the Fayum, the Nile Delta, near Asyut, and at Sai were built by people who may have engaged in regular residential mobility. This contrasts with Upper Egypt and 
Lower Nubia, where the earliest evidence for storage appears at sites with permanent architecture, although ephemeral sites are scattered through the surrounding areas. Farther south at Kerma, storage facilities first occur within a large, architecturally complex settlement with palisades. Echoing ethnographic observations of mobile people engaging in physical storage in different parts of the world, including pastoralists such as the Nuer in Sudan (Rowley-Conwy \& Zvelebil 1989:47; DeBoer 1988; Morton 2006), the archaeological record of the Sahara/Nile suggests that physical storage appears to have been useful to both mobile and sedentary people.

People in different areas located initial storage facilities and controlled storage in distinct ways. In the Fayum and Delta, the earliest storage pits may have been constructed and operated on a communal basis; Fayum pits are located on high ground away from settlements and flood areas. At Asyut and in Upper Egypt, initial storage construction and management occurred more on a household level. In Lower Nubia, A-Group people put storage facilities within houses, but also at special dedicated sites that might have been built and/or managed communally. At Sai, 8$\mathrm{B}-52 \mathrm{~A}$ is positioned in a favorable substrate on high ground far from any habitation; communal organization is possible but not certain. At Kerma, pits are interspersed among huts of standardized dimensions, which might suggest control by households or small kin groups.

Comparing the predictions stated in Table 2 with archaeological evidence shows people in different locations practiced physical storage in different ways, possibly with different motives. The only motive that contradicts the location and form of facilities all along the Nile is \#5: Concealing surpluses from elites or outsiders. For example, activities at 8-B-52A are visible from the entire northern half of the island. To conceal storage, people would have created smaller, more scattered caches at lower elevations or tucked in wadis, perhaps using jars hidden in Pleistocene gravels.

Finally, archaeological data from Sai demonstrate the limits of the predictions in Table 2, and in our ability to infer whether storage was managed by households or communities. People practicing some degree of residential mobility constructed a centralized storage facility in an advantageous location (i.e. with a pliable substrate), but this does not prove that storage was communally organized. It is equally possible that households or small kin groups managed specific pits or demarcated areas within the centralized facility at 8-B-52A.

\section{Subsequent economic and social change}

After physical storage facilities were established, economic and social changes proceeded in different ways in each location. In Lower Egypt, communal food storage facilities gave way to more household-based constructions. After several centuries specialized storage facilities were created for trade goods, which fueled the development of social differentiation. In Upper Egypt and Lower Nubia initial storage had diverse forms and locations and occurred in tandem with food production and long-distance exchange; social differentiation soon followed and in Upper Egypt accelerated through its unification with Lower Egypt.

In northern Sudan, storage continued for centuries at Sai Island with little elaboration from Early to Late Pre-Kerma times. Upstream at Kerma, however, massive pit facilities and other architectural features suggest that the motivations for storage quickly transformed during Middle and Late Pre-Kerma times. Perhaps the exceptional width of the alluvial plain at Kerma (Honegger 2006) supported plant food production on a larger scale, sufficient to accumulate surpluses that did not just furnish food security, but could be diverted for feasting and/or exchange. Once plant food production and storage were employed regularly, local environmental 
conditions and production capabilities allowed the rapid development of social differentiation culminating in the Kerma state.

These contrasts highlight the point that in some areas (e.g., Lower Egypt, Sai), storage facilities appear to serve a food security role for centuries without elaboration, while in other areas (e.g., Upper Egypt, Khor Daoud, Kerma) storage technology is quickly co-opted to facilitate accumulation and exchange. Now that diverging processes have been identified, researchers should weigh the full range of possible causal factors. These may include local environmental conditions (e.g., the large alluvial plain at Kerma), social or ideological variation between the various populations, and historical contingency.

\subsection{The choice between environmental and physical storage}

Social, environmental, and physical storage developed at different times in human prehistory. Of the three kinds, social storage appears to be most adaptable to varying degrees of mobility and different economic strategies, and poses no intrinsic conflict with either of the others.

Environmental and physical storage are compatible up to a point, but become mutually exclusive beyond a certain scale: Herding large flocks requires a degree of mobility incompatible with mass collection, harvesting and storage of plant resources in a fixed location.

Northeast Africa's unusual record of subsistence change - fishing/hunting/gathering, followed by mobile herding and finally sedentary farming - showcases the tensions between different forms of storage as people weigh competing priorities under a series of different conditions. Late Pleistocene people experimented with storage of fish, and possibly of plant foods, in a limited way. Early Holocene people experimented with both environmental storage (herding of cattle and tethering of Barbary sheep) and physical storage (large ceramic vessels at Khartoum, and pits and bins in the eastern Sahara), but practiced neither on a large scale. As the herding of cattle and small stock became common ways of coping with shifting resource patches across the Sahara, there is little evidence for further development of physical storage. Near the Nile, people living north of the $3^{\text {rd }}$ Cataract followed the Saharan pattern, but areas farther south with sufficiently predictable rainfall had conditions in which herders could follow a regular seasonal round between riversides and hinterlands; under these circumstances, it was possible to practice both environmental and physical storage simultaneously, and keep herding long after southwest Asian crops became available.

When increased aridity in the Middle Holocene made the Sahara uninhabitable even with environmental storage, better-watered areas such as the Fayum depression and the Nile attracted more intensive settlement. As deteriorating conditions curtailed movements away from water sources, physical storage and plant food production together emerged as the preferred strategy for mitigating seasonal and more long-term disparities in resource availability. Once these two practices were in place, however, innovations in economic and social organization proceeded in distinct ways in different areas.

\section{CONCLUSION}

Scholars often regard domestication events and the spread of crops and livestock into new areas as the ultimate watersheds in prehistoric subsistence change, which led human groups into new economic and social channels. Yet, food production is just one means of reducing risk or seasonal disparities in resource availability; storage, in all its various forms with their advantages and disadvantages in mobile or sedentary life, is another. 
Globally, ethnoarchaeological and archaeological research shows that novel domesticates, farming technologies, and agricultural practices are not always adopted quickly, universally, or irreversibly (Denham 2004; Smith 2001). The northeast African archaeological record provides an interesting example of this point: in some areas southwest Asian crops are present millennia before major lifestyle changes take hold. It also shows that this principle applies equally to storage. Both environmental and physical storage were known and practiced by people during the early Holocene. Over the next four millennia, people prioritized different kinds of storage in response to the changing opportunities and constraints they faced. Saharan landscapes with shifting patches of resources favored a strong emphasis on highly mobile environmental storage, which prevented the use of large-scale physical storage. Wetter landscapes near the Nile could support mobility on a regular seasonal round, such that environmental storage and physical storage could be practiced simultaneously. Deterioration of habitats suitable for herding, and concentration of resources in a tightly constrained area by the Nile, triggered de-emphasis of environmental storage and a heightened focus on physical storage. The history of subsistence change in northeast Africa thus need not be viewed as a chronicle of domestication events and spreading agricultural and pastoral practices, but as a perpetual balancing act between different known strategies for achieving a predictable food supply and satisfying social life.

Even as farming and physical storage became common along the Nile during the middle Holocene, people initially deployed these food security tools in locally distinctive ways, storing food communally or by household. Only in a few places did they rapidly translate the practice of storage into new social and economic spheres that galvanized social differentiation and longdistance trade. The origins of the Egyptian and Kerma states are due not only to the particular innovations in storage that took place in Upper Egypt and Kerma, but also to the social and environmental conditions that disinclined people in other areas such as Sai and the Fayum to pursue these types of innovations as rapidly or tenaciously. The northeast African archaeological record reveals no single narrative for changes in subsistence and society. Rather, its histories of storage, food production, and social change are complexly intertwined, and exhibit remarkable diversity.

\section{ACKNOWLEDGEMENTS}

We are grateful to the late Francis Geus, who led archaeological research at Sai for many years, initiated work at 8-B-52A, and invited EH to undertake research at Sai in 2004. Carla Geus assured continuation of the project in 2005 and generously made available records and images from Geus' fieldwork. Barbara Zach kindly furnished us with the original reports for Geus' dates on barley. Didier Devauchelle and Florence Doyen managed official and logistical operations for the Mission Archéologique de l'Île de Sai 2006-9. Sudan's National Corporations of Antiquities and Museums (NCAM) gave every possible assistance with government permits. Fieldwork was funded by the Chancellor William Danforth fund (2004) and National Science Foundation grant BCS0519434 (2005-2008). We are grateful to field assistants Jeff Stivers and Hélène Delattre and NCAM representative Sami Mohammed-Ali. The people of Sai Island made fieldwork possible and have our profound gratitude. Special thanks to Elena Garcea for valuable input during and after fieldwork, and Elizabeth Newman, Katheryn Twiss and two anonymous reviewers for their helpful comments. 


\section{REFERENCES CITED}

Akazawa, T., 1986. Hunter-gatherer adaptations and the transition to food production in Japan. In: Zvelebil, M. (Ed.), Hunters in Transition: Mesolithic Societies of Temperate Eurasia and their Transition to Farming. Cambridge University Press, Cambridge, pp. 151-155.

Allen, R.C., 1997. Agriculture and the origins of the state in ancient Egypt. Explorations in Economic History 34:135-154.

Barakat, H., 1990. Appendix 4: Plant remains from El Omari. In: Debono, F., Mortenson, B. (Eds.), El Omari: A Neolithic Settlement and Other Sites in the Vicinity of Wadi Hof, Helwan. Verlag Philipp von Zabern, Mainz, pp. 109-114.

Bard, K.A.,, 1994. The Egyptian Predynastic: a review of the evidence. Journal of Field Archaeology 21(3):265-288.

Barrier, C.R., 2010. Storage and relative surplus at the Mississippian site of Moundville. Journal of Anthropological Archaeology 30:206-219.

Binford, L., 1980. Willow smoke and dogs tails: hunter-gatherer settlement systems and site formation. American Antiquity 45(1):4-20.

Bogaard, A., Charles, M., Twiss, K., 2010. Food storage and sharing at Çatalhöyük: the botanical and faunal evidence. In: Benz, M. (Ed.), The Principle of Sharing: Segregation and Construction of Social Identities at the Transition from Foraging to Farming. Studies in Early Near Eastern Production, Subsistence and Environment 14. Ex oriente, Berlin: pp. 313-329.

Bonnet, C., 1992. Excavations at the Nubian royal town of Kerma: 1975-91. Antiquity 66(252):611-625.

Bonnet, C., 2006. Les établisments des cultures Kerma. In: Caneva, I., Roccati, A. (Eds.), Acta Nubica: Proceedings of the X International Conference of Nubian Studies. Istituto Polygrafico e Zecca dello Stato, Roma, pp. 15-20.

Brenton, B.P., 1995. The seasonality of storage. In: Huss-Ashmore, R. (Ed.), Coping with Seasonal Constraints. MASCA Research Papers in Science and Archaeology 5:45-54.

Bronk Ramsey, C. 2013. OxCal 4.2 Manual. Radiocarbon Accelerator Lab, Oxford University. https://c14.arch.ox.ac.uk/

Butzer, K.W., 1997. Late Quaternary problems of the Egyptian Nile: stratigraphy, environments, prehistory. Paléorient 23(2):151-173.

Caneva, I., Frangipane M., Palmieri A. 1987., Predynastic Egypt: new data from Maadi. African Archaeological Review 5:105-114. 
Caneva, I., Santucci, E., 2006. Late hunter-gatherer settlement pattern in central Sudan. In: Caneva, I., Roccati, A. (Eds.), Acta Nubica: Proceedings of the X International Conference of Nubian Studies. Istituto Polygrafico e Zecca dello Stato, Roma, pp. 45-49.

Coupland, G., 1988. Prehistoric economic and social change in the Tsimshian area. In: Isaac, B. (Ed.), Research in Economic Anthropology, Supplement 3: Prehistoric Economies of the Pacific Northwest Coast. JAI Press, Greenwich, CT, pp. 231-243.

Cunningham, P., 2011. Catching your savings: the use of small-scale storage in European prehistory. Journal of Anthropological Archaeology 30:135-144.

DeBoer, W.R., 1988. Subterranean storage and the organization of surplus: the view from eastern North America. Southeastern Archaeology 7(1):1-20.

Debono, F., Mortenson, B., 1990. El Omari: A Neolithic Settlement and Other Sites in the Vicinity of Wadi Hof, Helwan. Verlag Philipp von Zabern, Mainz.

Denham, T., 2008. Agricultural emergence and transfomation in the Upper Wahgi Valley, Papua New Guinea, during the Holocene. Holocene 18:481-496.

Despagne, R., n.d., Topographic data files for Sai Island. Geus archives.

di Lernia, S., 1998. Cultural control over wild animals during the early Holocene: the case of Barbary sheep in the central Sahara. In: di Lernia, S., Manzi, G. (Eds.), Before Food Production in North Africa. ABACO, Forli, pp. 113-126.

di Lernia, S. (Ed.), 1999. The Uan Afuda Cave: Hunter-Gatherer Societies of Central Sahara. All’Insegna del Giglio, Firenze.

di Lernia, S., 2001. Dismantling dung: delayed use of food resources among early Holocene foragers of the Libyan Sahara. Journal of Anthropological Archaeology 20:408-441.

Evans-Pritchard, E. 1940. The Nuer: A discription of the modes of livelihood and political institutions of a Nilotic people. Oxford University Press, Oxford.

Fahmy, A., 2005. Missing plant macroremains as indicators of plant exploitation in Predynastic Egypt. Vegetation History and Archaeobotany 14:287-294.

Flannery, K.V., 1972. The cultural evolution of civilizations. Annual Review of Ecology and Systematics 3:399-426.

Garcea, E., 2006-2007. The Holocene prehistory at Sai Island, Sudan. CRIPEL (Cahiers de Recherches de L'Institut de Papyrologie et d'Egyptologie de Lille) 26:107-113. 
Garcea, E., Hildebrand, E., 2009. Interregional interactions along the Nile during the Middle Holocene: ceramics from Sai Island. Journal of Anthropological Archaeology 28:304-322.

Gatto, M.C., 2000. The most ancient evidence of the "A-Groups" culture in Lower Nubia. In: Krzyzaniak, L., Kroeper, K., Kobusiewicz, M. (Eds.), Recent Research Into the Stone Age of Northeastern Africa. Poznań Archaeological Museum, Poznań: pp. 105-117.

Gatto, M.C., 2006. The Nubian A-Group: A reassessment. Archéonil Moyen 16:61-76.

Gautier, A., Van Neer, W., 1989. Animal remains from the Late Paleolithic sequence at Wadi Kubbaniya. In: Wendorf, F., Schild, R., (assemblers) Close, A., (Ed.), The Prehistory of Wadi Kubbaniya Volume 2: Stratigraphy, Paleoeonomy, and Environment. SMU, Dallas, pp. 118-161.

Geus, F., 1998. Saï 1996-1997. Archéologie du Nil Moyen 8: 85-126.

Geus, F., 1998-2002. Two seasons in Sai Island (1996-1997). Kush 18: 61-73.

Geus, F., 2000. Geomorphology and prehistory of Sai Island, Nubia: report on a current research project. In: Krzyzaniak, L., Kroeper, K., Kobusiewicz, M. (Eds.), Recent Research Into the Stone Age of Northeastern Africa. Poznań Archaeological Museum, Poznań: pp. 119-128.

Geus, F., 2004. Pre-Kerma storage pits on Sai Island. In: Kendall, T. (Ed.), Nubian Studies: Proceedings of the Ninth Conference of the International Society of Nubian Studies, 1998. Museum of Fine Arts and Northeastern University, Boston, pp. 46-51.

Haaland, R., 1995. Sedentism, cultivation, and plant domestication in the Holocene Middle Nile region. Journal of Field Archaeology 22(2):157-174.

Haaland, R., 1987. Socioeconomic Differentiation in Neolithic Sudan. BAR International Series 350, Oxford.

Haaland, R.,1989. The late Neolithic culture-historical sequence in the central Sudan. In: Krzyzaniak, L., Kobusiewicz, M. (Eds.), Late Prehistory of the Nile Basin and the Sahara. Poznań Archaeological Museum, Poznań, pp. 359-367.

Haaland, R., 1995. Sedentism, cultivation and plant domestication in the Holocene Middle Nile region. Journal of Field Archaeology 22(2):158-174.

Halstead, P., 1989. The economy has a normal surplus: economic stability and social change among early farming communities of Thessaly, Greece. In: Halstead, P., O’Shea, J. (Eds.), Bad Year Economics: Cultural Responses to Risk and Uncertainty. Cambridge University Press, Cambridge, pp. 68-80. 
Halstead, P., O’Shea, J., 1989. Introduction: Cultural responses to risk and uncertainty. In: Halstead, P., O’Shea, J. (Eds.), Bad Year Economics: Cultural Responses to Risk and Uncertainty. Cambridge University Press, Cambridge, pp. 1-7.

Hassan, F., 1985. A radiocarbon chronology of Neolithic and Predynastic sites in Upper Egypt and the Delta. African Archaeological Review 3:95-116.

Hassan, F., 1988. The Predynastic of Egypt. Journal of World Prehistory 2(2):135-185.

Hayden, B.,1990. Nimrods, piscators, pluckers, and planters: The emergence of food production. Journal of Anthropological Archaeology 9:31-69.

Hayden, B., 2009. The proof is in the pudding: feasting and the origins of domestication. Current Anthropology 50(5):597-561.

Hendrickx, S., Vermeersch, P., 2003. Prehistory: from the Paleolithic to the Badarian culture. In: Shaw, I. (Ed.), The Oxford History of Ancient Egypt. Oxford: Oxford University, pp. 16-40.

Hildebrand, E.A., 2006-2007. The significance of Sai Island for early food production in Sudan. CRIPEL (Cahiers de Recherches de L'Institut de Papyrologie et d'Egyptologie de Lille) 26:173182.

Hitchcock, R.K., 1982. Patterns of sedentism among the Basarwa of eastern Botswana. In: Leacock, E., Lee, R. (Eds.), Politics and History in Band Societies. Cambridge University Press, Cambridge, pp. 223-269.

Holmes, D., Friedman, R., 1994. Survey and test excavations in the Badari region, Egypt. Proceedings of the Prehistoric Society 60:105-142.

Honegger, M., 2003. Exploitation du territoire et habitat dans les sociétés pastorales du Soudan: L'exemple de Kerma entre les $5^{\mathrm{e}}$ et $3^{\mathrm{e}}$ millénaires av. J.-C. Cahiers d'Archéologie Romande 95: Hommage à Alain Gallay. SRO-Kunding SA, Châtelaine/Genève, pp. 341-352.

Honegger, M., 2004a. The Pre-Kerma settlement: new elements throw light on the rise of the first Nubian kingdom. In: Kendall, T. (Ed.), Nubian Studies 1998: Proceedings of the Ninth Conference of the International Society of Nubian Studies. Northeastern University, Boston, pp. 83-94.

Honegger, M., 2004b. The Pre-Kerma: a cultural group from Upper Nubia prior to the Kerma civilisation. Sudan \& Nubia 8:38-46.

Honegger, M., 2006. Habitats préhistoriques en Nubie entre le $8^{\mathrm{e}}$ et le $3 \mathrm{e}$ millenaire av. J.-C.: l'exemple de la region de Kerma. In: Caneva, I., Roccati, A. (Eds.), Acta Nubica: Proceedings of the X International Conference of Nubian Studies. Istituto Polygrafico e Zecca dello Stato, Roma, pp. 3-13. 
Ingold, T., 1983. The significance of storage in hunting societies. Man 18(3):553-571.

Khabir, A., 1987. New radiocarbon dates for Sarurab 2 and the age of the Early Khartoum Tradition. Current Anthropology 28:377-380.

Krzyzaniak, L., 1991. Early farming in the Middle Nile basin: recent discoveries at Kadero (Central Sudan). Antiquity 65:515-532.

Kuper, R., Kröpelin, S., 2006. Climate-controlled Holocene occupation of the Sahara: motor of Africa's evolution. Science 313:803-807.

Lal, B.B., 1967. Indian archaeological expedition to Nubia, 1962: a preliminary report. Fouilles en Nubie (1961-1963): 99-118.

Lange, M., 2006. The archaeology of the Laqiya Region (NW-Sudan): ceramics, chronology and cultures. In: Caneva, I., Roccati, A. (Eds.), Acta Nubica: Proceedings of the X International Conference of Nubian Studies. Istituto Polygrafico e Zecca dello Stato, Roma, pp. 107-115.

Lange, M., 2007. Development of pottery production in the Laqiya region, Eastern Sahara. CRIPEL (Cahiers de Recherches de L'Institut de Papyrologie et d'Egyptologie de Lille) 26:243251.

Madella, M., García-Granero, J., Out, W., Ryans, P., Usai, D. 2014. Microbotanical evidence of domestic cereals in Africa 7000 years ago. PLOS One 9(10):1-9.

Magid, A., Caneva, I., 1998. Economic strategy based on food-plants in the early Holocene central Sudan: a reconsideration. In: di Lernia, S., Manzi, G., (Eds.), Before Food Production in North Africa. ABACO, Forli, pp. 79-90.

Marshall, F., Hildebrand, E., 2002. Cattle before crops: the beginnings of food production in Africa. Journal of World Prehistory 16(2):99-143.

Meurillon, L., 1997. Les Greniers Pre-Kerma de l'Île de Sai. Unpublished MA thesis, University of Lille III, France.

Midant-Reynes, B., 2000. The Prehistory of Egypt: From the First Egyptians to the First Pharoahs. Blackwell, London.

Minc, L., Smith, K., 1989. The spirit of survival: cultural responses to resource variablility in North Alaska. In: Halstead, P., O'Shea, J. (Eds.), Bad Year Economics: Cultural Responses to Risk and Uncertainty. Cambridge University Press, Cambridge, pp. 8-40.

Mohammed-Ali, A., 1982. The Neolithic Period in the Sudan, c. 6000-2500 BC. Oxford: British Archaeological Reports \#139. 
Morton, Chris. 2006. "Nuer storage pots." Southern Sudan Project, Pitt Rivers Museum. Accessed 23 Jan. $2016<$ http://southernsudan.prm.ox.ac.uk/details/1998.355.599.2/>

Myers, O.H., 1958. Abka re-excavated. Kush VI:131-141.

Myers, O.H., 1960. Abka again. Kush VIII:174-181.

Nicoll, K., 2004. Recent environmental change and prehistoric human activity in Egypt and northern Sudan. Quaternary Science Reviews 23, 561-580.

Nordström, H.-Å., 1972. Neolithic and A-Group Sites. Uppsala: Scandanavian University Books.

O'Shea, J., 1981. Coping with scarcity: exchange and social storage. In: Sheridan, A., Bailey, G. (Eds.), Economic Archaeology. BAR International S96, Oxford, pp. 167-186.

Pearson, R., 2006. Jomon hot spot: increasing sedentism in south-western Japan in the Incipient Jomon (14,000-9250 cal. BC) and Earliest Jomon (9250-5300 cal. BC) periods. World Archaeology 38(2):239-258.

Reinold, J. 2000. Archéologie au Soudan: Les civilisations de Nubie. Éditions d'Errance, Paris.

Reinold, J. 2001. Kadruka and the Neolithic in the northern Dongola Reach. Sudan \& Nubia 5:210 .

Reinold, J. 2006. Les cimetières préhistoriques au Soudan - cotoumes funéraires et systemes sociaux. In: Caneva, I., Roccati, A. (Eds.), Acta Nubica: Proceedings of the X International Conference of Nubian Studies. Istituto Polygrafico e Zecca dello Stato, Roma, pp. 139-162.

Rowley-Conwy, P., Zvelebil, M. 1989. Saving it for later: storage by prehistoric hunter-gatherers in Europe. In: Halstead, P., O’Shea, J. (Eds.), Bad Year Economics: Cultural Responses to Risk and Uncertainty. Cambridge University Press, Cambridge, pp. 40-57.

Sakaguchi, T., 2009. Storage adaptations among hunter-gatherers: a quantitative approach to the Jomon period. Journal of Anthropological Archaeology 28:290-303.

Salvatori, S., Usai, D. (Eds.), 2008. A Neolithic cemetery in the Northern Dongola Reach (Sudan): Excavation at Site R12. Sudan Archaeological Research Society, London.

Sassaman, K., 2004. Complex hunter-gatherers in evolution and history: a North American perspective. Journal of Archaeological Research 12(3): 227-280.

Shiner, J., 1968. The Khartoum Variant industry. In: Wendorf, F. (Ed.), The Prehistory of Nubia. SMU Press, Dallas, pp. 768-790.

Smith, B.D., 2001. Low-level food production. Journal of Anthropological Research 9:1-43. 
Soffer, O., 1989. Storage, sedentism and the Eurasian Paleolithic record. Antiquity 83:719-732.

Testart, A., 1982. The significance of food storage among hunter-gatherers: residence patterns, population densities, and social inequalities. Current Anthropology 23(5):523-537.

Vermeersch, P., Paulissen, E., Van Neer, W., 1989. The Late Paleolithic Makhdama sites (Egypt): environment and subsistence. In: Krzyzaniak, L., Kobusiewicz, M. (Eds.), Late Prehistory of the Nile Basin and the Sahara. Poznań Archaeological Museum, Poznań: pp. 87114.

Vermeersch, P., 1998. Fishing along the Nile. In: di Lernia, S., Manzi, G. (Eds.), Before Food Production in North Africa. ABACO, Forli, pp. 103-112.

Wasylikowa, K., Mitka, J., Wendorf, F., Schild, R., 1997. Exploitation of wild plants by the early Neolithic hunter-gatherers of the Western Desert, Egypt: Nabta Playa as a case study. Antiquity 71(274): 932-941.

Wasylikowa, K., Harlan J.R., Evans, J., Wendorf, F., Schild, R., Close, A.E., Krolik, H., Housley, R.A., 1993. Examination of botanical remains from early Neolithic houses at Nabta Playa, Western Desert, Egypt, with special reference to sorghum grains. In: Shaw, T., Sinclair, P., Andah, B., Okpoko, A. (Eds.), The Archaeology of Africa: Food, Metals, and Towns. Routledge, London, pp. 154-164.

Wendorf, F., Schild, R., 1989. Summary and synthesis. In: Wendorf, F., Schild, R. (assemblers), Close, A. (Ed.), The Prehistory of Wadi Kubbaniya Volume 3: Late Paleolithic Archaeology. SMU, Dallas, pp. 768-824.

Wendorf, F., Schild, R., 1998. Nabta Playa and its role in northeast African prehistory. Journal of Anthropological Archaeology 17: 97-123.

Wendorf, F., Schild, R., 2002. Introduction. In: Wendorf, F., Schild, R., \& Associates (Eds.), Holocene Settlement of the Egyptian Sahara Volume 1: The Archaeology of Nabta Playa. SMU, Dallas, pp. 1-10.

Wendorf, F., Close A.E., Schild, R., 1989. Early domestic cattle and scientific methodology. In: Krzyzaniak, L., Kobusiewicz, M. (Eds.), Late Prehistory of the Nile Basin and the Sahara. Poznań Archaeological Museum, Poznań, pp. 61-68.

Wendorf, F., Close A.E., Schild, R., Waylikowa, K., 1991. The Combined Prehistoric Expedition: results of the 1990 and 1991 seasons. American Research Center in Egypt Newsletter 154:1-8.

Wendorf, F., Close A.E., Schild, R., Waylikowa, K., Housely, R.A., Harlan, J.R., Krolik, H., 1992. Saharan exploitation of plants 8000 years ago. Nature 359:721-724 
Wendrich, W., Taylor, R.E., Southon, J., 2009. Dating stratified settlement sites at Kom K and Kom W: fifth millennium BCE radiocarbon ages for the Fayum Neolithic. Nuclear Instruments and Methods in Physics Research B 268(7-8):999-1002.

Wenke, R.J., Buck, P., Hanley, J.R., Lane, M.E., Long, J., Redding, R., 1983. The Fayyum Archaeological Project: preliminary report of the 1981 season. American Research Center in Egypt Newsletter 122:25-40.

Wenke, R.J., Long, J.E., Buck., P.E., 1988. Epipaleolithic and Neolithic subsistence and settlement in the Fayyum Oasis of Egypt. Journal of Field Archaeology 15(1): 29-51.

Wesson, C., 1999. Chiefly power and food storage in southeastern North America. World Archaeology 31(1):145-164.

Wetterstrom, W., 1993. Foraging and farming in Egypt: the transition from hunting and gathering to horticulture in the Nile Valley. In: Shaw, T., Sinclair, P., Andah, B., Okpoko, A. (Eds.), The Archaeology of Africa: Food, Metals, and Towns. Routledge, London, pp. 165-226.

Wickens, G., 1982. Paleobotanical speculations and Quaternary environments in the Sudan. In Williams, M.A.J., Adamson, D.A. (Eds.), A Land Between Two Niles. Balkema, Rotterdam, pp. 23-50.

Wiessner, P., 1982. Risk, reciprocity and social influences on !Kung San economics. In: Leacock E., Lee, R., (Eds.), Politics and History in Band Societies. Cambridge University Press, Cambridge, pp. 61-85.

Winters, H.D., 1974. Introduction to the new edition. In: Webb, W.S., Indian Knoll (2 ${ }^{\text {nd }}$ edition). UT Press, Knoxville, pp. v-xxvii.

Zohary, D., Hopf, M., 2000. Domestication of Plants in the Old World ( ${ }^{\text {rd }}$ Edition). Oxford University Press, Oxford.

Zvelebil, M., 1986. Mesolithic societies and the transition to farming. In: Zvelebil, M. (Ed.), Hunters in Transition: Mesolithic Societies of Temperate Eurasia and their Transition to Farming. Cambridge University Press, Cambridge, pp. 167-188.

Zvelebil, M., Rowley-Conwy, P., 1986. Foragers and farmers in Atlantic Europe. In: Zvelebil, M. (Ed.), Hunters in Transition: Mesolithic Societies of Temperate Eurasia and their Transition to Farming. Cambridge University Press, Cambridge, pp. 67-93. 


\section{LIST OF FIGURES}

Figure 1. Locations of sites and areas mentioned in text. $A$ - Central Sahara: Uan Afuda; $B$ - Nile Delta: El Omari, Maadi, Merimde; $C$ - Fayum: FS-1, Kom K; $D$ - Middle Egypt (Asyut area): Deir al Tasr, Hemamieh, Matmar, Mostegedda; $E$ - Upper Egypt (Qena/Nagada area): KH1, KH3; Makhadma 2 and 4; $F-1^{\text {st }}$ Cataract: Wadi Kubbaniya; $G$ - Western Desert: Nabta E-75-6 and E-75-8; $H$ - Lower Nubia (south): Afiyah, CPE 604, CPE 1029, CPE 2002, DIW-5, Khor Bahan, Khor Daoud, Myers' Abka sites V and IX, SJE 365, SJE 369, SJE 371, SJE 414; I- Sai Island: 8-B-10A, 8-B-10C, 8-B-52A, 8-B-53, 8-B-76; $J-3^{\text {rd }}$ Cataract: Kerma, R12, Kadruka KDK sites; $K$ - From Atbara/Nile confluence area to Khartoum: Abu Darbein, Ed Damer, El Ghaba, Kadero, Early Khartoum, Khartoum Hospital, Sarurab, Shaheinab, Um Direiwa, Zakiab; Nile cataracts are numbered.

Figure 2. Topographic map of Sai Island, with relevant archaeological sites indicated. The Jebel Adou outcrop of the Nubian Sandstone Formation (JA) rises $75 \mathrm{~m}$ above a surrounding pediment of gravel-rich Pleistocene river terraces with elevations $>200 \mathrm{~m}$ above sea level. Mudstone layers of the Nubian Sandstone are covered by the Pleistocene pediment in most parts of the island, but visible as surface outcrops in a few places (M). Peripheral parts of the island have silt/clay river terraces deposited in the early to mid Holocene (Geus 2000). Scattered areas have a thin cap of late Holocene aeolian sediment.

Figure 3. Surface cleaning and excavation at 8-B-52A. Dark grey ellipses indicate openings of pits excavated by Geus team in 1996-7 and 2002-3. Medium grey ellipses indicate openings of pits seen on surface, but not yet excavated. Pale grey grid shows areas subject to surface cleaning.

Figure 4. Probability distribution for calibrated dates from 8-B-52A (2-sigmas using OxCal v4.2.4 (Bronk Ramsey 2013)).

Figure 5. Profiles for seven pits at 8-B-52A. Top row: shallow basin-shaped pits. Middle row: cylindrical pits. Lower left: bell-shaped pit. Lower right: Basin-shaped upper chamber with bellshaped lower chamber.

Figure 6. Morphology and volume of pits at 8-B-52A. Top: Pit shapes with respect to maximum depth and diameter. Middle: Histogram of excavated pit volumes. Bottom: Volume averages, and ranges for excavated pits of various shapes. 


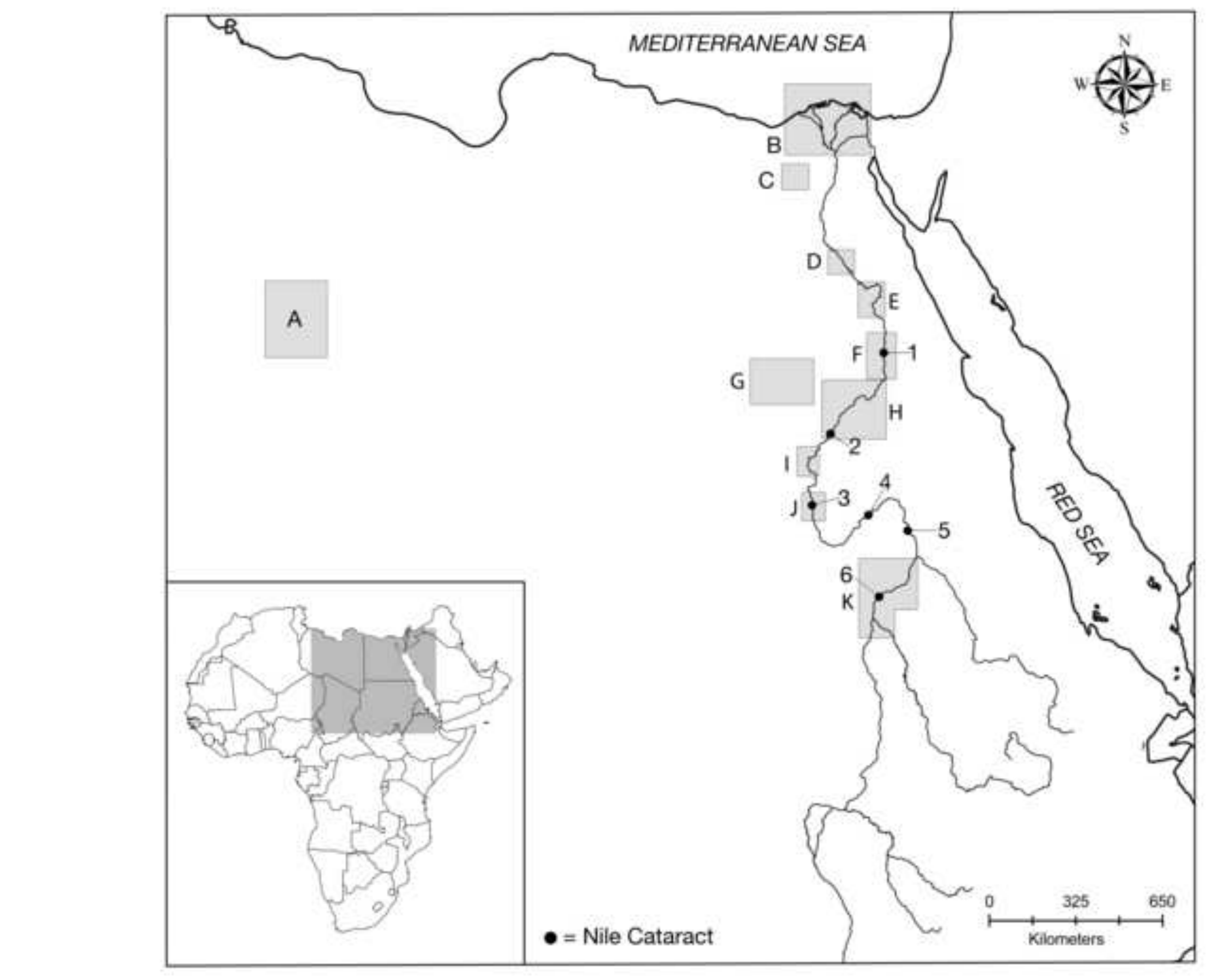




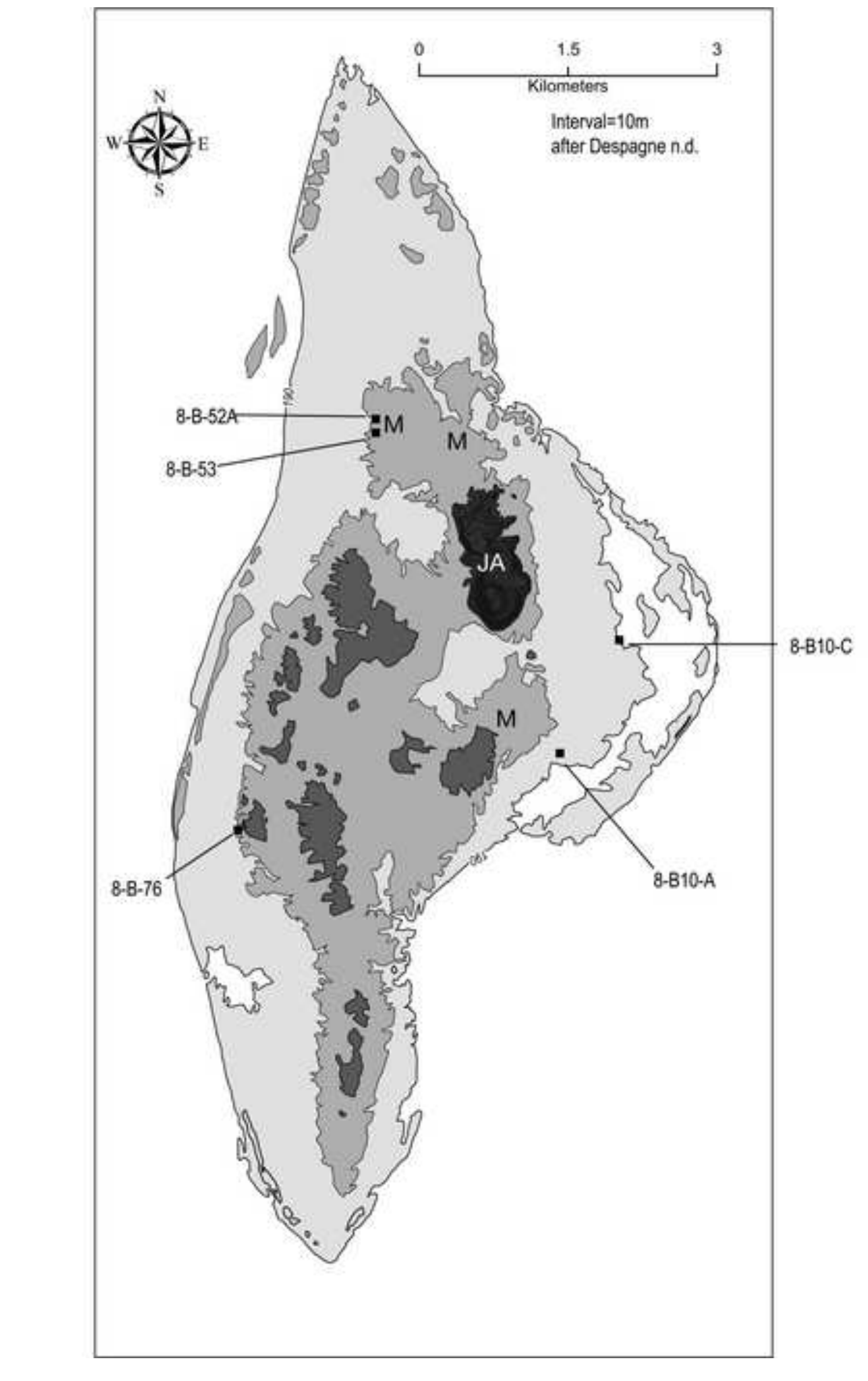

Figure 2

interval $=10 \mathrm{~m}$

after Despagne n.d.

-B10-C

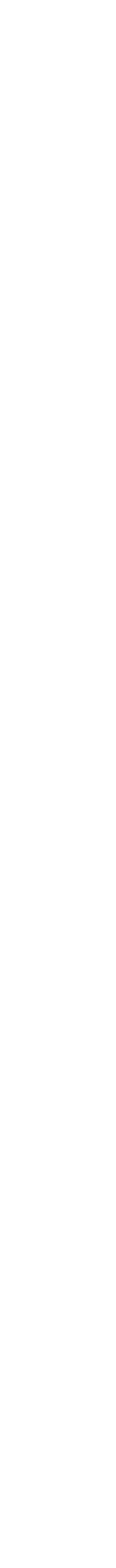




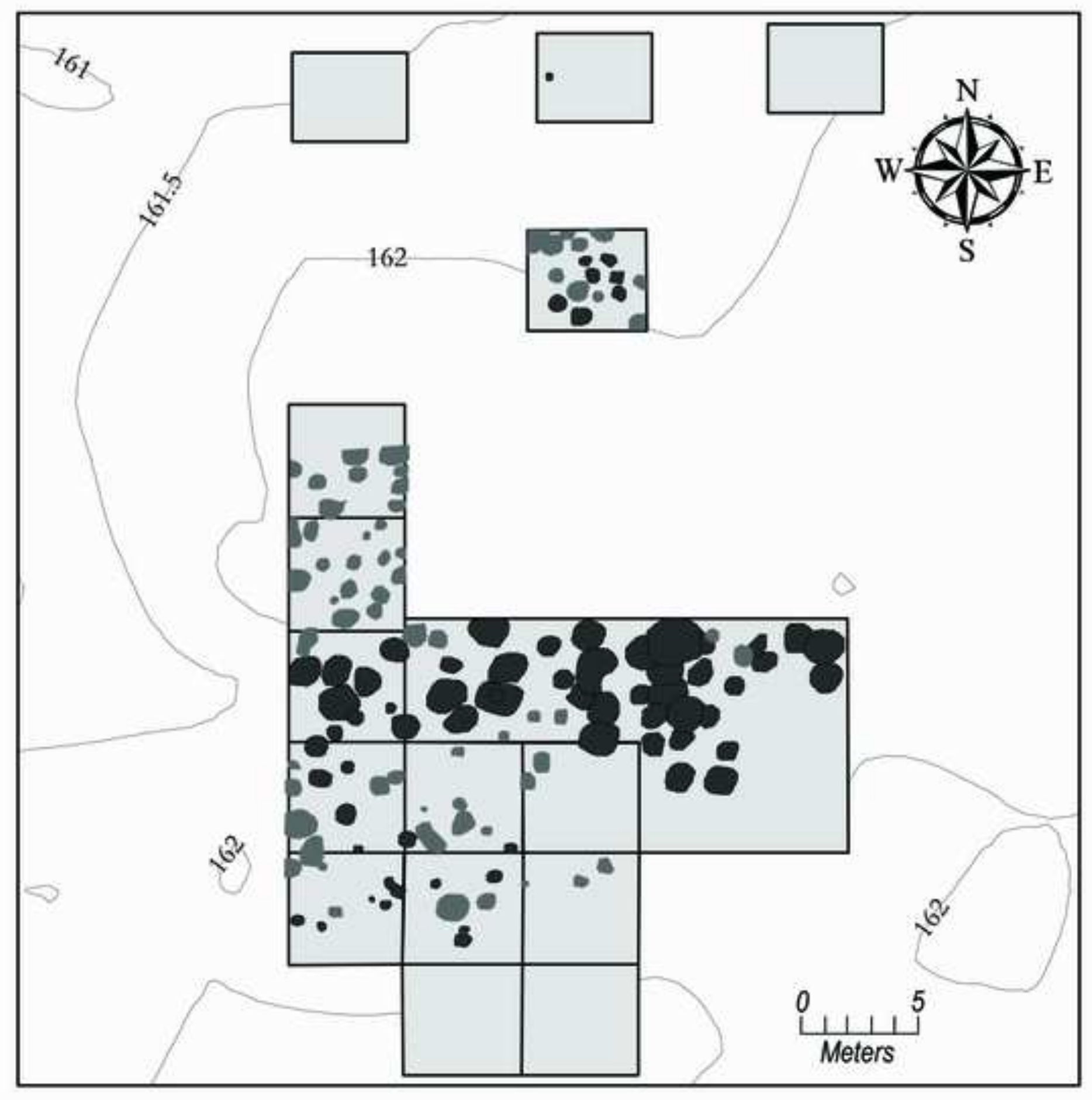

Figure 3 


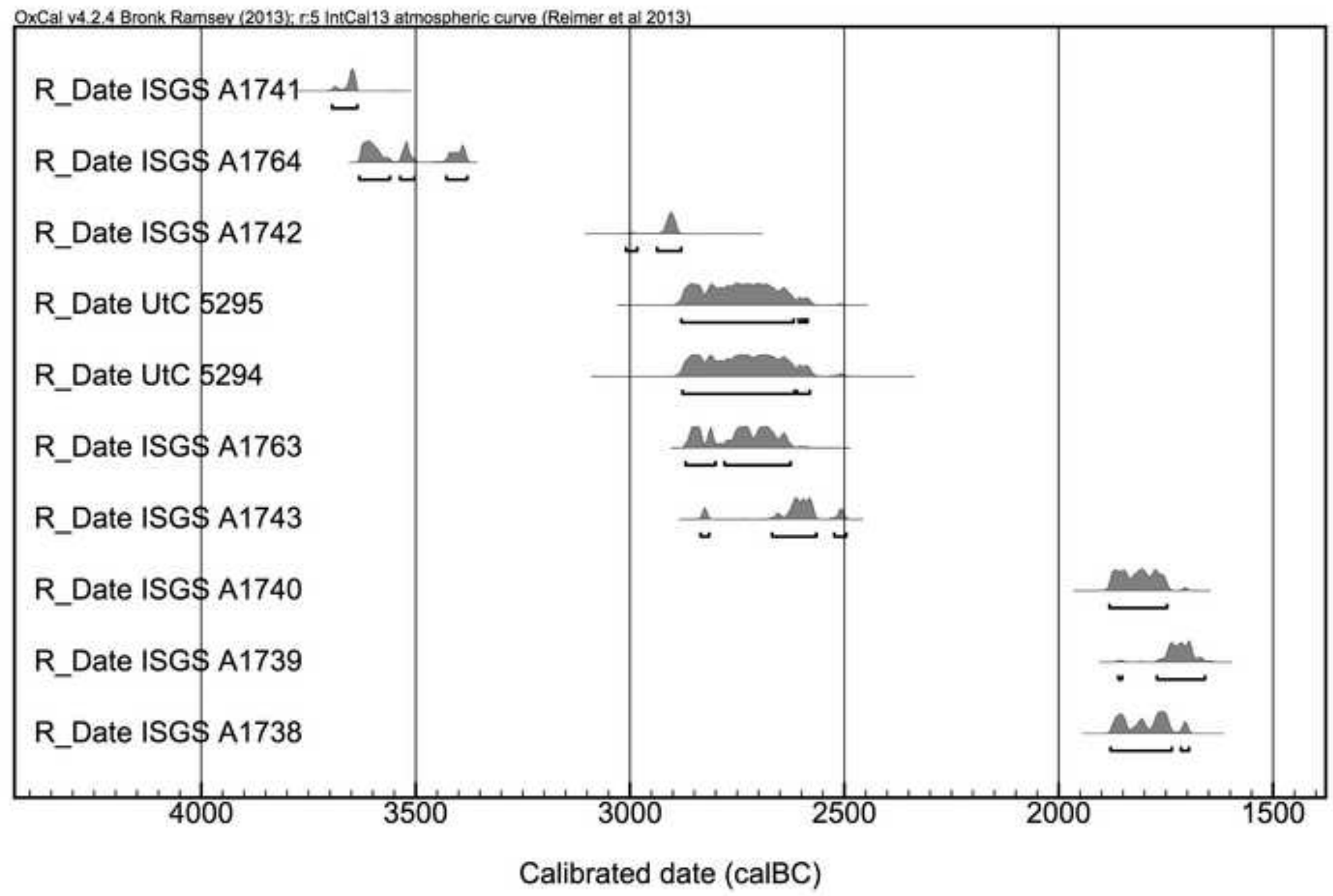


Silo 3

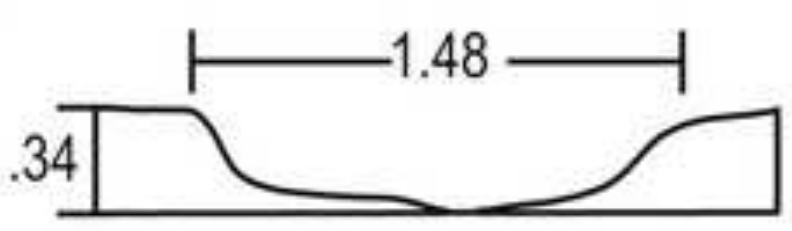

Silo 11
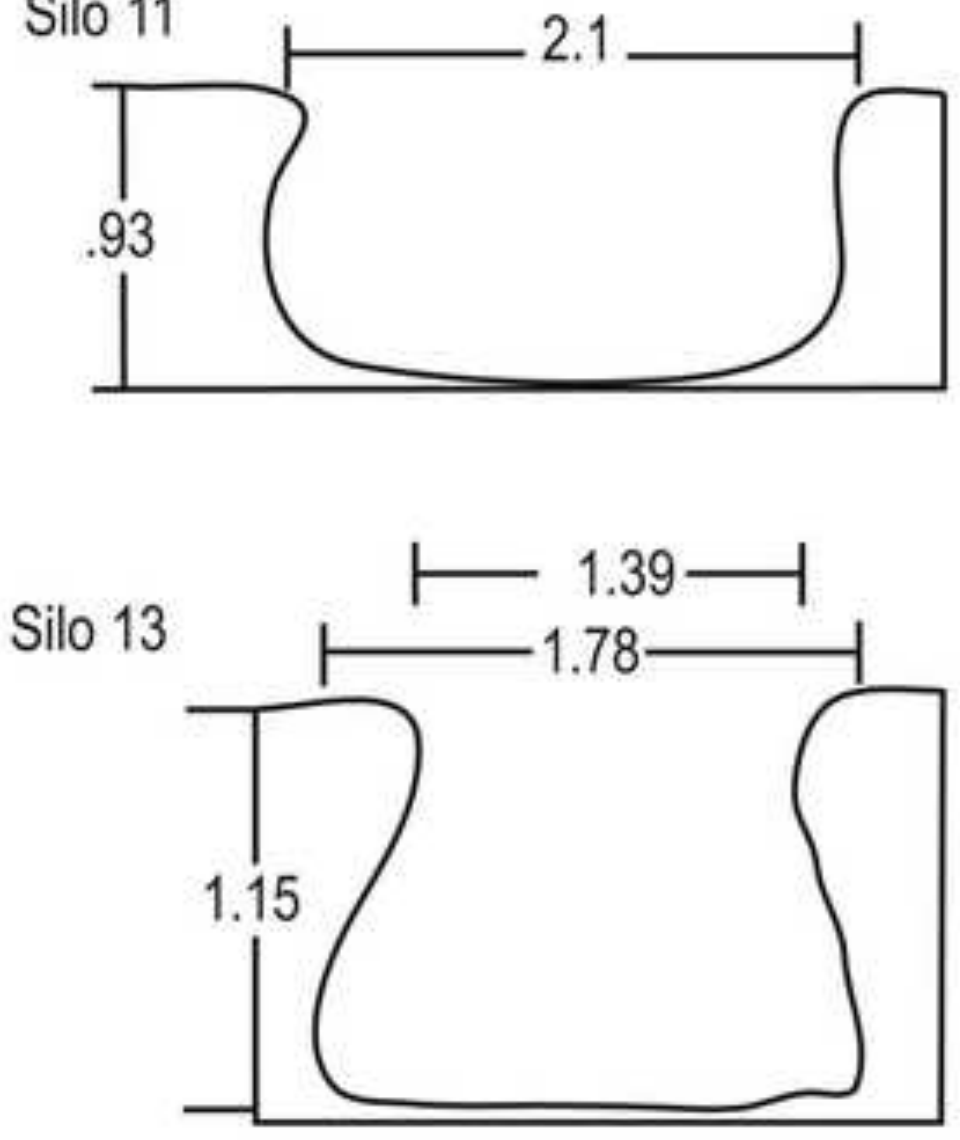

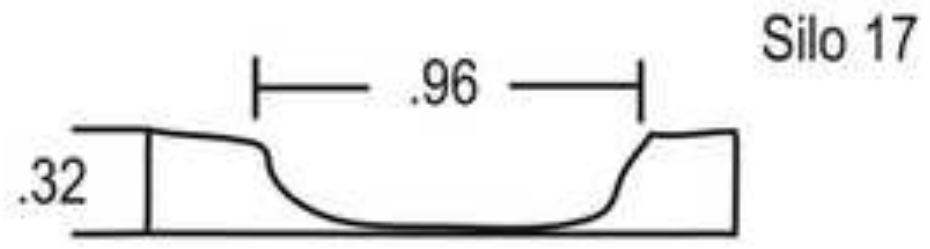

Silo 17 (L) Silo $20(R)$
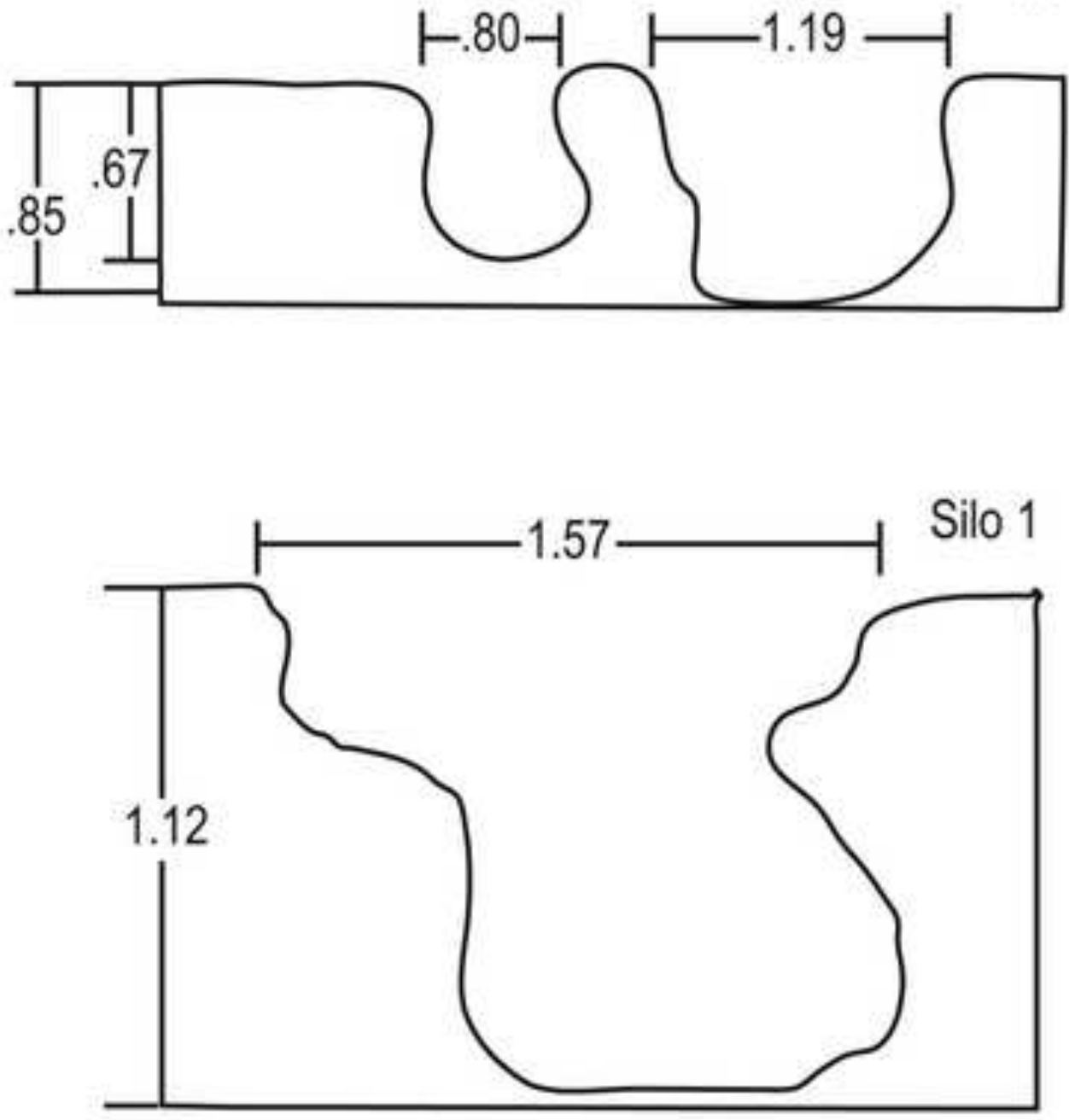

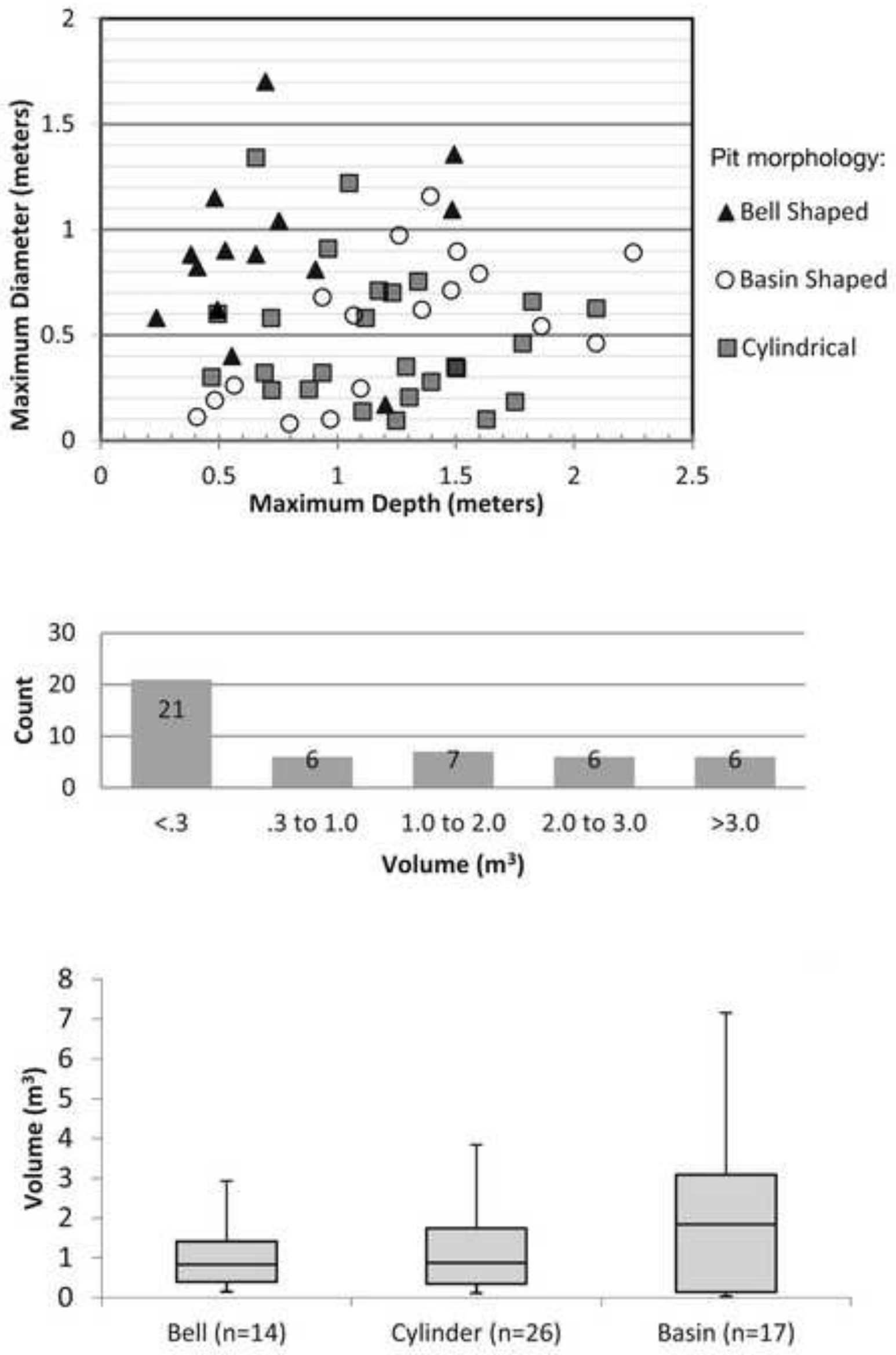
Table 1. Possible archaeological evidence for different forms of storage in the Sahara and Nile regions before the arrival of southwest Asian crops. Some information is site-specific and some can be generalized beyond sites to broader material culture complexes. Location for sites is indicated in Figure 1.

\begin{tabular}{|c|c|c|}
\hline Site/Date/Type of storage & Description and contextual information & References \\
\hline $\begin{array}{l}\text { Wadi Kubbaniya } \\
18,000 \text { bp } \\
\text { Delayed consumption }\end{array}$ & $\begin{array}{l}\text { Harvesting Cyperus tubers would have triggered denser re- } \\
\text { growth. In some seasons tubers required grinding or pounding to } \\
\text { be palatable. Surplus fish and tubers might have been roasted } \\
\text { and/or dried for later consumption during lean months. }\end{array}$ & $\begin{array}{l}\text { Gautier \& Van Neer } \\
\text { 1989:147-152; Wendorf } \\
\text { \& Schild 1989:822-823 }\end{array}$ \\
\hline $\begin{array}{l}\text { Makhdama } 2 \& 4 \\
13,000-12,000 \mathrm{bp} \\
\text { Possible physical storage }\end{array}$ & $\begin{array}{l}\text { Sites on high ground above the Nile floodplain were re-used } \\
\text { repeatedly for fishing-related activities during certain seasons. } \\
\text { Postholes and large concentrations of charcoal suggest possible } \\
\text { smoking of fish on racks. Pits present, but purpose unknown. }\end{array}$ & $\begin{array}{l}\text { Butzer 1997; } \\
\text { Vermeersch et al. 1989; } \\
\text { Vermeersch } 1998\end{array}$ \\
\hline $\begin{array}{l}\text { Uan Afuda } \\
\text { 9000-8000 bp } \\
\text { Environmental storage }\end{array}$ & $\begin{array}{l}\text { People penned wild Barbary sheep in rear portions of } \\
\text { rockshelter within a Saharan massif. }\end{array}$ & $\begin{array}{l}\text { di Lernia 1998, 1999, } \\
2001\end{array}$ \\
\hline $\begin{array}{l}\text { Nabta Playa } \\
9000-8000 \text { bp } \\
\text { Environmental storage; } \\
\text { small scale physical storage }\end{array}$ & $\begin{array}{l}\text { People created walk-in wells so animals could reach water } \\
\text { below the ground surface. Although wild vs. domestic status of } \\
\text { Bos at Nabta is uncertain, wells suggest human efforts to } \\
\text { manage animal populations. Nabta dwellers harvested wild } \\
\text { cereals. Pits suggest physical storage. }\end{array}$ & $\begin{array}{l}\text { Wendorf et al. 1989, } \\
\text { 1991, 1992; Wendorf \& } \\
\text { Schild 1998, 2002; } \\
\text { Wasylikowa et al. 1993, } \\
\text { 1997. }\end{array}$ \\
\hline $\begin{array}{l}\text { Khartoum Mesolithic sites } \\
9000-6500 \text { bp } \\
\text { Possible small-scale } \\
\text { physical storage }\end{array}$ & $\begin{array}{l}\text { Large ceramic vessels at Khartoum Mesolithic sites along Nile } \\
\text { (eg. Early Khartoum, Khartoum Hospital, Abu Darbein, } \\
\text { Aneibis, Ed Damer, Sarurab) may have been storage containers, } \\
\text { but no evidence is found for large-scale physical storage } \\
\text { facilities or environmental storage. }\end{array}$ & $\begin{array}{l}\text { Haaland 1995; Magid } \\
\text { \& Caneva 1998; Khabir } \\
1987\end{array}$ \\
\hline $\begin{array}{l}\text { Sai 8-B-10C } 6000 \text { bp } \\
\text { Possible small-scale } \\
\text { physical storage }\end{array}$ & $\begin{array}{l}\text { Several pits are found in large horizontal excavation area } \\
\text { together with hearths and post-holes aligned in hut } \\
\text { configurations at Khartoum Variant site near the Nile channel. }\end{array}$ & $\begin{array}{l}\text { Garcea 2006-2007; } \\
\text { Garcea \& Hildebrand } \\
2009\end{array}$ \\
\hline $\begin{array}{l}\text { Abkan sites } \\
6000-5000 \mathrm{bp} \\
\text { Environmental storage }\end{array}$ & $\begin{array}{l}\text { Faunal use focuses on wild resources but includes livestock at } \\
\text { some sites. Sites (eg. CPE 604, 1029, 2002; SJE 365, 369, 371, } \\
\text { 414; Myers sites V, IX; and Sai 8-B-76) cluster near the Nile but } \\
\text { suggest high mobility. }\end{array}$ & $\begin{array}{l}\text { Lange 2006; Nordström } \\
\text { 1972, 2006; Myers } \\
\text { 1958, 1960; Shiner } \\
\text { 1968; pers. obs. }\end{array}$ \\
\hline $\begin{array}{l}\text { Khartoum Neolithic sites } \\
5800-5000 \text { bp } \\
\text { Environmental storage in } \\
\text { variable environment }\end{array}$ & $\begin{array}{l}\text { Grinding of wild cereals is prominent at some base camp sites } \\
\text { (eg. Kadero I \& II, Umm Direiwa I); seasonal fishing and } \\
\text { herding activities dominate at Zakiab. Cemeteries (Kadero) with } \\
\text { ornamented individuals suggest some social differentiation. } \\
\text { Away from the Nile few sites are found, possibly suggesting } \\
\text { high mobility by herders. }\end{array}$ & $\begin{array}{l}\text { Caneva \& Santucci } \\
\text { 2006; Haaland 1987, } \\
\text { 1989; Krzyzaniak 1991; } \\
\text { Mohammed-Ali } 1982\end{array}$ \\
\hline
\end{tabular}


Table 2. Motivations for physical storage, and predicted sizes, configurations and locations of storage facilities.

\begin{tabular}{|l|l|l|l|}
\hline Motivation & Size & Configuration & Location \\
\hline $\begin{array}{l}\text { Mitigate unpredictability or seasonal } \\
\text { scarcity (household) }\end{array}$ & Small & Decentralized & In or around dwelling structures \\
\hline $\begin{array}{l}\text { Mitigate unpredictability or seasonal } \\
\text { scarcity (community) }\end{array}$ & Large & Centralized & $\begin{array}{l}\text { One facility near dwelling } \\
\text { structures }\end{array}$ \\
\hline $\begin{array}{l}\text { Accumulate products to attain personal } \\
\text { wealth }\end{array}$ & $\begin{array}{l}\text { Small, } \\
\text { medium }\end{array}$ & Decentralized & In or around dwelling structures \\
\hline $\begin{array}{l}\text { Collect community products to advance } \\
\text { the aims of aspiring elites }\end{array}$ & Large & Centralized & $\begin{array}{l}\text { One facility near dwelling } \\
\text { structures }\end{array}$ \\
\hline Conceal surpluses from elites or outsiders & Small & Decentralized & $\begin{array}{l}\text { Scattered locations away from } \\
\text { habitation area }\end{array}$ \\
\hline
\end{tabular}


Table 3. Archaeological evidence for large-scale, durable physical storage facilities in the Sahara and Nile regions during/after the arrival of southwest Asian crops. Some sites are grouped; others are presented individually. Site locations are indicated in Figure 1.

\begin{tabular}{|c|c|c|c|c|}
\hline & $\begin{array}{l}\text { Area or Site } \\
\text { Date }{ }^{14} \mathrm{Cbp} \\
\text { Date cal BCE }\end{array}$ & $\begin{array}{l}\text { Site, crops, other relevant } \\
\text { information }\end{array}$ & $\begin{array}{l}\text { Evidence for storage } \\
\text { facilities }\end{array}$ & References \\
\hline \multirow{4}{*}{ 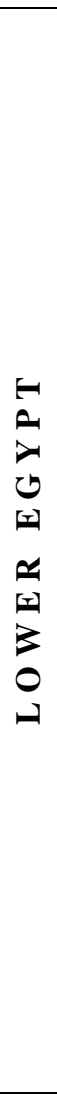 } & $\begin{array}{l}\frac{\text { Fayum A }}{5760-5540 \text { bp }} \\
4600-4400 \text { cal BCE }\end{array}$ & $\begin{array}{l}\text { Kom K has emmer, barley, and flax } \\
\text { textile. } \\
\text { FS-1 has grindstones, stone tools } \\
\text { with 'sickle' polish, wild \& } \\
\text { domestic plants \& animals; artifact } \\
\text { distributions suggest seasonal use as } \\
\text { playa levels fluctuated. }\end{array}$ & $\begin{array}{l}\text { Outcrop near Kom K has } 150 \\
\text { pits with cereal and other plant } \\
\text { remains. }\end{array}$ & $\begin{array}{l}\text { Hassan 1988:150; } \\
\text { Wenke et al. 1983: } \\
\text { 39-40, 1988:44-47; } \\
\text { Wendrich et al. 2009; } \\
\text { Wetterstrom 1993: } \\
\text { 205-6. }\end{array}$ \\
\hline & $\begin{array}{l}\text { Merimde } \\
5900-5500 \text { bp } \\
4800-4400 \text { cal BCE }\end{array}$ & $\begin{array}{l}\text { Emmer, barley, lentils, peas, and } \\
\text { flax; wild legumes, sedges, and } \\
\text { weed species. }\end{array}$ & $\begin{array}{l}\text { Phase I: shallow pits of } \\
\text { ambiguous purpose. } \\
\text { Phases II-IV: large mud-lined } \\
\text { pits by individual pit houses. } \\
\text { Phase V: basket silos. Hassan } \\
\text { suggests households } \\
\text { controlled storage. } \\
\end{array}$ & $\begin{array}{l}\text { Hassan 1988; } \\
\text { Wetterstrom 1993; } \\
\text { Zohary \& Hopf } \\
\text { 2000:219 }\end{array}$ \\
\hline & $\begin{array}{l}\text { El Omari } \\
5500-5200 \mathrm{bp} \\
4100 \mathrm{cal} \text { BCE }\end{array}$ & $\begin{array}{l}\text { Emmer, club, and einkorn wheats, } \\
\text { rye-grass, barley, vetches, flax, pea; } \\
\text { wild Rumex pulcher, Echium } \\
\text { rawolfii, Emex spinosus, Lathyrus } \\
\text { spp., Thesium humile, Polygonum } \\
\text { sp., Ceruana pratensis. }\end{array}$ & $\begin{array}{l}\text { Initial site use focuses on } \\
\text { storage pits, not settlement. } \\
\text { Later, baskets are incorporated } \\
\text { within storage pits. Finally the } \\
\text { site became a focus of human } \\
\text { habitation. }\end{array}$ & $\begin{array}{l}\text { Barakat 1990; } \\
\text { Debono \& Mortenson } \\
\text { 1990:20-21, 81; } \\
\text { Hassan 1988:159 }\end{array}$ \\
\hline & $\begin{array}{l}\text { Maadi } \\
4900-4600 \text { bp } \\
3650 \mathrm{BCE}\end{array}$ & $\begin{array}{l}\text { Einkorn, emmer, Triticum aestivum, } \\
\text { Triticum spelta, barley, lentils, and } \\
\text { peas. }\end{array}$ & $\begin{array}{l}\text { Initial storage focuses on } \\
\text { household subsistence goods. } \\
\text { Later specialized facilities } \\
\text { store goods other than } \\
\text { foodstuffs, some of which } \\
\text { were acquired from Upper } \\
\text { Egypt and the Levant. }\end{array}$ & $\begin{array}{l}\text { Caneva et al. 1987; } \\
\text { Midant-Reynes } \\
\text { 2000:213-215 }\end{array}$ \\
\hline \multirow[t]{2}{*}{ 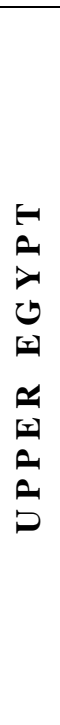 } & $\begin{array}{l}\text { Badarian sites near } \\
\frac{\text { Asyut }}{\sim 5200} \text { bp } \\
4000 \text { cal BCE }\end{array}$ & $\begin{array}{l}\text { Deir al Tasr, Matmar, Mostegedda, } \\
\text { Hemamieh. Barley, wheat, and } \\
\text { lentils; use of local Cyperus tubers } \\
\text { and other wild plants appears to } \\
\text { have continued. People probably } \\
\text { had a still somewhat mobile } \\
\text { existence. }\end{array}$ & $\begin{array}{l}\text { Small huts and storage pits } \\
\text { resemble those in middle } \\
\text { phases at Merimde. Some } \\
\text { large pits }(\sim 2.5 \mathrm{~m} \text { in diameter } \\
\text { and } 3 \mathrm{~m} \text { in depth) may } \\
\text { indicate heavy dependence on } \\
\text { farming (Hassan } 1988) \text { or a } \\
\text { different organization of } \\
\text { storage (community- rather } \\
\text { than household-based), or the } \\
\text { need to store more foods of all } \\
\text { kinds (domestic and wild). }\end{array}$ & $\begin{array}{l}\text { Hassan 1988:153-4; } \\
\text { Hendrickx \& } \\
\text { Vermeersch 2003; } \\
\text { Holmes \& Friedman } \\
\text { 1994; Midant-Reynes } \\
\text { 2000:160 }\end{array}$ \\
\hline & $\begin{array}{l}\frac{\text { Amratian sites near }}{\text { Nagada }} \\
\sim 5100-4700 \text { bp } \\
3840-3680 \text { cal BCE }\end{array}$ & $\begin{array}{l}\text { KH1, KH3. } \\
\text { Emmer, barley, pea, vetch and flax, } \\
\text { and field weeds demonstrate local } \\
\text { farming; people also ate wild melon, } \\
\text { Cyperus tubers, and Ziziphus and } \\
\text { other wild fruits. }\end{array}$ & $\begin{array}{l}\text { Mud-lined pits, and storage } \\
\text { pits within houses. }\end{array}$ & $\begin{array}{l}\text { Fahmy 2005; Hassan } \\
\text { 1985; Bard 1994:273; } \\
\text { Hassan 1988:155 }\end{array}$ \\
\hline
\end{tabular}


Table 4. Dates from 8-B-10A and 8-B-52A, Sai Island. UtC dates were obtained by Geus (1998) on barley remains identified by K. Neumann and Barbara Zach (letter on file, Geus archives), with souce contexts provided by Barbara Zach (pers. comm). ISGS dating samples were submitted by the authors. Calibrated date ranges (2-sigma throughout) were obtained using OxCal v. 4.2.4 (Bronk Ramsey 2013).

\begin{tabular}{|c|c|c|c|c|c|}
\hline Lab number & Site & Material dated & $\begin{array}{l}\text { Conventional } \\
\text { age }\left({ }^{14} \mathrm{C} \text { bp }\right)\end{array}$ & $\delta^{13} \mathrm{C}$ & $\begin{array}{l}95.4 \% \\
\text { probability } \\
\text { range BCE }\end{array}$ \\
\hline ISGS A1741 & $8-B-52 A$ & Chaff from Silo 70 daub seal & $4865 \pm 20$ & $*$ & $3696-3637$ \\
\hline ISGS A1764 & $8-\mathrm{B}-52 \mathrm{~A}$ & Chaff from Silo 26 daub seal & $4730 \pm 20$ & $*$ & $3632-3380$ \\
\hline ISGS A1742 & $8-B-52 A$ & Chaff from Silo 10 daub seal & $4300 \pm 25$ & $*$ & $3010-2881$ \\
\hline UtC 5295 & $8-\mathrm{B}-52 \mathrm{~A}$ & Barley from Silo 11 & $4151 \pm 44$ & -25.5 & $2881-2587$ \\
\hline UtC 5294 & $8-B-52 A$ & Barley from Silo 1 & $4142 \pm 48$ & -28.8 & $2878-2581$ \\
\hline ISGS A1763 & $8-B-52 A$ & Charcoal from Silo 39 daub seal & $4140 \pm 20$ & -16.7 & $2871-2626$ \\
\hline ISGS A1743 & $8-\mathrm{B}-52 \mathrm{~A}$ & Charcoal from Silo 11 daub seal & $4070 \pm 20$ & -18.9 & $2836-2496$ \\
\hline ISGS A1740 & 8-B-10A & Charcoal, Bag \#94 (lower deposits) & $3485 \pm 20$ & -26.8 & $1882-1748$ \\
\hline ISGS A1739 & $8-\mathrm{B}-10 \mathrm{~A}$ & Charcoal, Bag \# 64, Find I (middle deposits) & $3420 \pm 20$ & -27.5 & $1861-1659$ \\
\hline ISGS A1738 & $8-\mathrm{B}-10 \mathrm{~A}$ & Charcoal, Bag \#31, Find B (upper deposits) & $3465 \pm 20$ & -25.1 & $1880-1697$ \\
\hline
\end{tabular}

* Sample was too small for a $\delta^{13} \mathrm{C}$ reading 